IZA DP No. 7404

The Role of Institutions and Firm Heterogeneity for Labour Market Adjustment:

Cross-Country Firm-Level Evidence

Peter N. Gal

Alexander Hijzen

Zoltan Wolf

May 2013 


\title{
The Role of Institutions and Firm Heterogeneity for Labour Market Adjustment: Cross-Country Firm-Level Evidence
}

\author{
Peter N. Gal \\ Tinbergen Institute, VU University Amsterdam and OECD \\ Alexander Hijzen \\ $O E C D$ and IZA \\ Zoltan Wolf \\ U.S. Bureau of the Census \\ Discussion Paper No. 7404 \\ May 2013 \\ IZA \\ P.O. Box 7240 \\ 53072 Bonn \\ Germany \\ Phone: +49-228-3894-0 \\ Fax: +49-228-3894-180 \\ E-mail: iza@iza.org
}

\begin{abstract}
Any opinions expressed here are those of the author(s) and not those of IZA. Research published in this series may include views on policy, but the institute itself takes no institutional policy positions. The IZA research network is committed to the IZA Guiding Principles of Research Integrity.

The Institute for the Study of Labor (IZA) in Bonn is a local and virtual international research center and a place of communication between science, politics and business. IZA is an independent nonprofit organization supported by Deutsche Post Foundation. The center is associated with the University of Bonn and offers a stimulating research environment through its international network, workshops and conferences, data service, project support, research visits and doctoral program. IZA engages in (i) original and internationally competitive research in all fields of labor economics, (ii) development of policy concepts, and (iii) dissemination of research results and concepts to the interested public.
\end{abstract}

IZA Discussion Papers often represent preliminary work and are circulated to encourage discussion. Citation of such a paper should account for its provisional character. A revised version may be available directly from the author. 


\section{ABSTRACT}

\section{The Role of Institutions and Firm Heterogeneity for Labour Market Adjustment: Cross-Country Firm-Level Evidence*}

This paper investigates the role of policies and institutions for aggregate labour market dynamics during the recent financial crisis using firm-level data. First, it provides comparable estimates on firm-level labor adjustment by country, industry and firm size. Second, using variance decomposition methods, it shows that differences in firm-level labor adjustment accounts for about $40 \%$ of the cross-country variation in aggregate employment growth at the outset of the crisis. We interpret this as evidence that differences in institutional settings accounted for a substantial part of the variation in aggregate employment growth. Third, we find that stronger protection for regular workers is associated with lower (higher) employment (earnings-per-worker) response in the wake of output shocks. This suggests employment protection shifts the burden of adjustment from the extensive to the intensive margin. However, in explaining the diverse cross-country patterns in employment adjustment during the crisis, the impact of employment protection alone seems to be small.

JEL Classification: E24, J23

Keywords: labour market adjustment, employment protection, global financial crisis

Corresponding author:

Alexander Hijzen

OECD

2 , rue André-Pascal

75775 Paris Cedex 16

France

E-mail: alexander.hijzen@oecd.org

\footnotetext{
* This paper is based on an OECD project on labour market resilience. The authors would like to thank Eric Bartelsman, Andrea Bassanini, Bart Hobijn, Mark Keese, John Martin, Stefano Scarpetta and Ken Swinnerton as well as participants of the CAED 2012 Conference for helpful comments and suggestions. Sebastien Martin provided excellent research assistance. Financial support under project grant VS2010/0617 - SI576449 from the European Commission is gratefully acknowledged. All remaining errors are our own.
} 


\section{Introduction}

All OECD countries have been severely hit by the global financial crisis starting in 2008. However, the extent to which the decline in aggregate demand translated into lower employment has differed dramatically across countries (Figure 1, and OECD, 2012). In some of them, much of the adjustment in the labour market has been in terms of labour shedding (e.g. Spain and the U.S.). In others, where firms have tended to hoard labour (e.g. Germany, Japan) employment declined less. These differences can be explained by a number of factors: variation in shocks and agents' responses to them; differences in economic structures; and institutional characteristics of countries.

Figure 1: The relationship between output and employment change (2008-09)

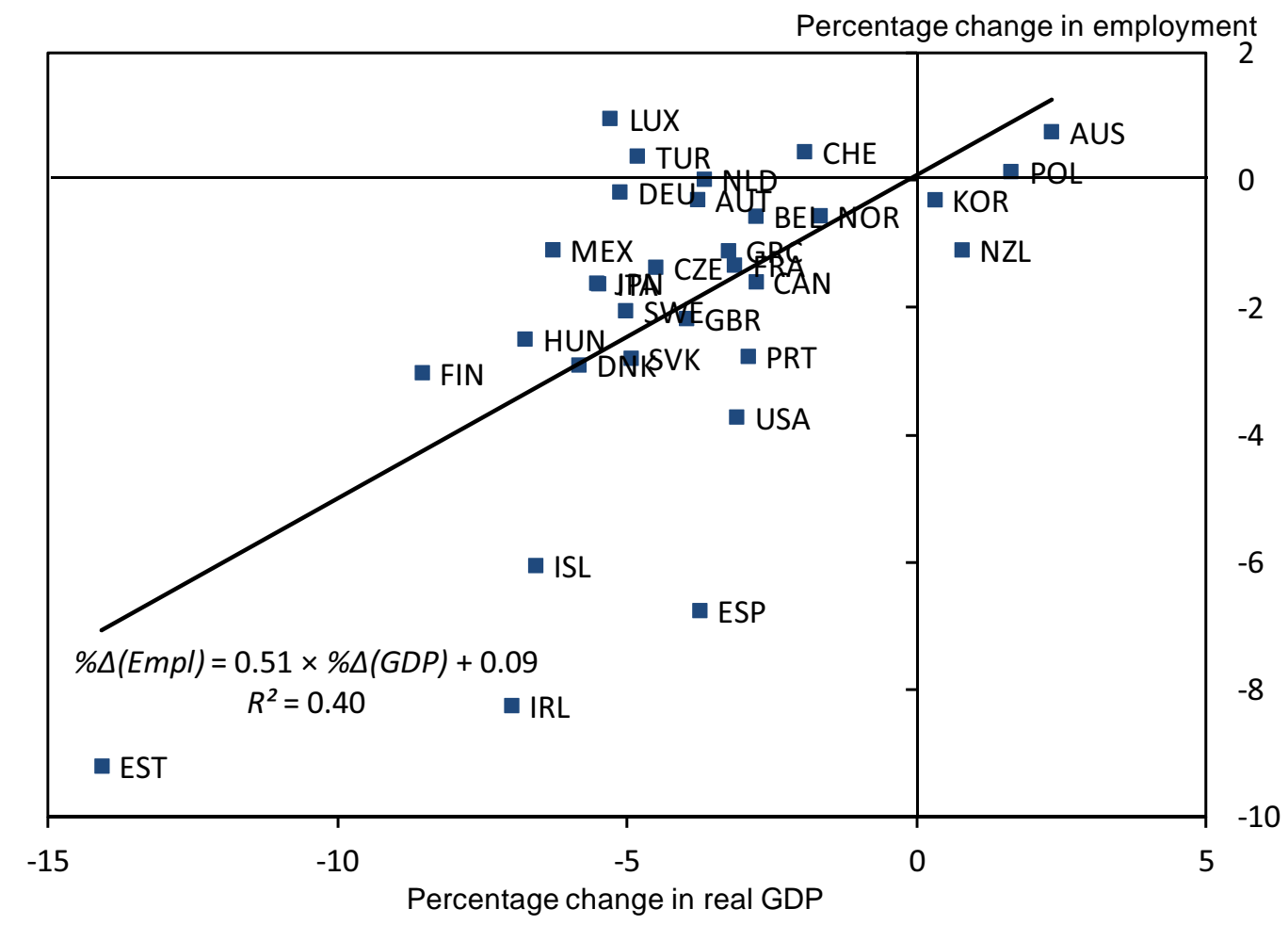

Source: OECD and authors' calculations.

As Figure 1 illustrates, during the crisis, differences in the size of aggregate shocks played an important role, although a substantial part of the variation in employment dynamics is left unexplained. For example, in Germany and Japan, manufacturing industries suffered the most from the decline in aggregate demand. In contrast, the construction sector was hit particularly hard in Ireland, Spain and the US, where it had tended to grow rapidly before the crisis as a result of the housing bubble. Since firm-specific human capital tends to be less important in construction than in manufacturing, construction firms may adjust their labour inputs more quickly in response to falling output. In other words, there may be a role for firm-heterogeneity in shaping the diverse aggregate responses: cross-country differences in the distribution of output shocks across heterogeneous firms as well as differences in their composition can account for some of the observed differences in aggregate employment. ${ }^{1}$

\footnotetext{
${ }^{1}$ Indeed, it can be shown that during the global financial crisis, labor market outcomes diverged within coun-
} 
This large variation in the employment impact of the crisis across countries also raises important questions about the role of policies and institutions. A number of studies have sought to analyse their role for shaping the impact of economic downturns on labour markets using aggregate data (e.g. Blanchard and Wolfers, 2000; Bassanini and Duval, 2009; OECD, 2012). While these studies have provided useful insights about the potential role of policies and institutions for the way labour markets adjust in response to shocks, it tends to be difficult to isolate the impact of specific policies and institutions using the cross-country variation in the data because of their correlation across countries (e.g. Belot and van Ours, 2004). ${ }^{2}$ Moreover, there is also a risk that aggregate studies of this kind leave a considerable part of the cross-country variation unexplained by ignoring the role of firm heterogeneity and differences in economic structures.

This paper investigates the role of policies and institutions for aggregate labour market dynamics during the global financial crisis using firm-level data. The advantages of firm-level data are twofold. On the one hand, it allows us to control for firm-heterogeneity, differences in the composition of firms and the distribution of shocks when understanding aggregate dynamics. On the other hand, we can use within-country variation as well as across country variation to identify the impact of institutions.

In light of these issues, the present paper makes the following contributions. First, using comprehensive and comparable firm-level data for 20 OECD countries for the period 1993-2009, we estimate the responsiveness of employment and earnings per worker to output shocks across countries, industries and firm-size groups. Second, using a semi-aggregated dataset of estimated output elasticities, employment shares and output shocks by the same breakdown, we employ variance decomposition methods to assess the relative contribution of cross-country differences in economic structure ( "structure heterogeneity"); the distribution of output shocks across different types of firms ("shock heterogeneity"); and the responsiveness of labour inputs to output shocks ( "response heterogeneity") in explaining the cross-country variation in aggregate employment growth during the crisis. Assuming labor market institutions affect elasticities but not output shocks or economic structures, the variance explained by heterogeneity in elasticities can be interpreted as an upper bound on the effect of institutions.

Third, the role of specific policies and institutions for response heterogeneity is analysed. Specifically, we investigate the role of two important labour market institutions for which withincountry as well as cross-country variation are both available: employment protection legislation (EPL) and the incidence of temporary work. Finally, we also assess briefly the implications of our key findings for aggregate labour market dynamics during the crisis.

The paper contributes to at least two branches of the literature. First, the analysis fits the line of papers about the role of market institutions for labor market outcomes. Previous studies followed either macro- or micro-economic approaches. The former exploit the variation across many countries (Layard and Nickell, 1999; OECD, 2006 and 2012; Bassanini and Duval, 2009), the latter use variation in microeconomic data from a single country or a restricted set

tries. The increase in within-country dispersion during a downturn is consistent with previous work on uncertainty by Bloom (2009) and provides a first indication that using disaggregate data instead of aggregate data can add to understanding aggregate labor market dynamics.

${ }^{2}$ This is due to that institutions are typically defined at the country level and correlated with each other across countries. This simultaneity implies that least squares coefficients of hand-picked institutional variables are biased estimates of true effects unless all institutions are controlled for in the regression. 
of countries that allow exploiting the within-country variation (Bassanini et al., 2009; Cingano et al., 2010). ${ }^{3}$ A recent paper by LaFontaine and Sivadasan (2009) falls somewhere in between in the sense that it uses plant-level data for a single multinational firm across more than 40 countries, but exploits the cross-country variation to assess the role of labour market rigidities for employment adjustment. While our paper is close in spirit to theirs, we look at the whole market economy and several thousand firms in each of the 20 countries in our sample. Further, we exploit both across and within country variation for two labor market institutions where data availability allows us to do so, EPL and temporary work. The impact of the former is identified using firm size exemptions, while the impact of the latter by the incidence of temporary work across firm size and industry groups. ${ }^{4,5}$

By and large, the present paper also relates to the literature that assesses aggregate implications of the way firms adjust to shocks at the micro level (Caballero et al., 1997; Davis et al., 2011). Those studies emphasized the importance of non-linearities in adjustment technologies for aggregate dynamics. Under the assumption that institutional settings do not affect the composition of employment across firms or the distribution of output shocks in the short-run, we also assess the implications of our key findings for aggregate labour market dynamics during the crisis. However, the focus of our analysis is not the role of non-linearities but the heterogeneity in adjustment technologies.

The remainder of the paper is organized as follows. Section 2 describes: i) the methodology that is used to estimate the responsiveness of employment and earnings per worker with respect to output; ii) puts forward a variance decomposition that is used to quantify the relative importance of structure, shock and response heterogeneity for aggregate employment growth during the crisis; and iii) introduces the framework to analyze the role of institutions for the responsiveness of employment and earnings per worker to output shocks. Section 3 gives a short description of the data used for the different parts of the analysis. Section 4 presents the results. Section 5 lays out the aggregate implications of our key findings, and the final section concludes.

\section{Methodology}

Given our main focus on the immediate response following the crisis, we maintain two important assumptions throughout the analysis. First, labour market institutions affect the adjustment of firms to output shocks, but not the distribution of output shocks or employment across different groups of firms. While economic structures and the distribution of shocks are clearly endogenous in the long run, this assumption allows us to use our micro-economic estimates for making inferences about aggregate labour market dynamics in the short run. Second, the

\footnotetext{
${ }^{3}$ A number of recent papers (ECB, 2012; Hobijn and Sahin, 2012) also investigate the cross-country patterns in employment during the crisis, using data on vacancies and unemployment and focusing on policies affecting labour market matching.

${ }^{4}$ Firm size exemptions have been used before to analyse the role of EPL in specific countries, but not yet in a cross-country context (see Venn, 2010, for details).

${ }^{5}$ Put differently, our analysis follows microeconomic studies in that the elasticities are estimated using firmlevel data. However, we deviate from those studies in that data is collected in a comprehensive manner from a multitude of countries. Our approach is related to macroeconomic studies in that one of the objectives is to explain cross-country variation in employment growth. However, it is different in that we do it by making use of within-country variation.
} 
adjustment technology is assumed to be homogeneous and constant over time for each firm group. ${ }^{6}$

\subsection{Estimating labour adjustment at the firm level}

We take a simple reduced form dynamic labour adjustment equation as the basis for obtaining estimates of output elasticities of employment and also of earnings per worker

$$
l_{i t}=\gamma l_{i t-1}+\beta y_{i t}+\eta_{i}+\varepsilon_{i t}
$$

where $l_{i t}$ denotes the labour input variable of interest in firm $i$ in year $t, y_{i t}$ denotes output (measured by turnover) in firm $i$ in year $t, \eta_{i}$ denotes firm-fixed effects and $\varepsilon_{i t}$ denotes an error term. Both the labour input variable and output are expressed in logs. Given the focus of the present paper on short-run adjustment, especially over the crisis, the analysis will focus on the short-term output elasticities, i.e. differences in the estimates of $\beta$-s. ${ }^{7}$

We consider two labour input variables: employment and earnings per worker. The focus on earnings per worker in addition to employment is motivated by our aim to account for different margins of labour input adjustment. Macroeconomic evidence shows that in countries such as Spain and the United States, labour market adjustment related to the crisis has overwhelmingly taken the form of labour shedding (external margin). In countries such Germany and Japan, where firms have tended to hoard labour and reduce working hours (internal margin) much of the decline in employment has been avoided. Turning to the role of adjustment through wages, macroeconomic evidence with respect to real hourly wages is less reliable due to the role of composition effects. ${ }^{8}$ Nevertheless, there is suggestive evidence that real wage adjustments have been relatively important in Central and Eastern European countries (OECD, 2012). As our cross-country firm level data do not allow differentiating between changes in working time and real wage effects, the analysis focuses on earnings per worker instead.

Equation 2.1 is a reduced form, and focuses only on output elasticity and leaves out many determinants of labour demand. For our purposes of identifying differences in responsiveness across countries and firm types, however, it is compatible with a variety structural models. For example, it is consistent with labour demand models which assume that firms do not fully adjust instantaneously because of the presence of quadratic adjustment costs (Gould, 1968; Hamermesh, 1993), but also provides a valid approximation when adjustment costs have a more complex structure (e.g. non-convex) due to the smoothing effect of aggregation across firms and over time. ${ }^{9}$

\footnotetext{
${ }^{6}$ Our assumption of the stability of labour market response to shocks is also supported by a recent study by Ball et al (2013) where they show that even during the recent crisis and in most countries, Okun's law coefficients did not change substantially. Moreover, they also show that differences across countries in terms of their responsiveness are much more important than the variation of responses over time, hinting at the role of labour market institutions which tend to be change only slowly and gradually over time.

${ }^{7}$ Note that the long run elasticities $\beta /(1-\gamma)$ are primarily driven by technological factors such as productivity growth and the general trend in capital-labour substitution, whereas our current aim is to assess the role of policies in shaping the short-run response to the crisis.

${ }^{8}$ Namely, the fact that less efficient workers with lower wages are more likely to be dismissed during a downturn increases average wages.

${ }^{9}$ Annual data is likely to be "overaggregated" in time, meaning it does not match the timing of firm decisions. Consequently, annual employment data may signal smoother adjustment than quarterly or monthly
} 
Equation 2.1 is estimated by country * industry ${ }^{*}$ firm size class cells (or firm groups) to allow for variation in the coefficients across each of these dimensions. To control for the endogeneity of output and lagged labour inputs, we apply a generalized method of moments estimator described in Arellano and Bond (1991). ${ }^{10}$ The estimated output elasticities are used as inputs for the variance decomposition and the analysis of institutions. In order to ensure that the estimated output elasticities are reasonable, we make use of the following rules. First, we disregard any output elasticities that do not satisfy the restriction $0<\hat{\beta}<1$ as these are considered to be implausible. Second, we disregard any output elasticities if (i) the number of instruments $(j)$ is large relative to the sample size $(N)$ and (ii) Hansen's test of over-identifying restrictions rejects the null of the orthogonality of the instrument matrix and estimated errors. An estimate is considered to be acceptable if (i) $j / N<0.3$ and (ii) Hansen's test does not reject at the $5 \%$ level. $^{11}$

\subsection{Decomposing cross-country heterogeneity in aggregate employment growth}

What accounts for the increased dispersion in aggregate employment growth across countries during the global financial crisis, and what is the potential role of policies and institutions? We take a first pass at these questions by decomposing the cross-country variation in aggregate employment growth into the respective contributions of three sources of heterogeneity: crosscountry differences in economic structure ("structure heterogeneity"); the distribution of output shocks across different types of firms ("shock heterogeneity"); and the responsiveness of labour inputs to output shocks ( "response heterogeneity") ${ }^{12}$

We start by defining the predicted growth rate of log employment, $\widehat{\Delta l}_{c j s}$, in country $c$, industry $j$ and size class $s$ as:

$$
\widehat{\Delta l}_{c j s} \doteq \beta_{c j s} \Delta y_{c j s}
$$

where $\beta_{c j s}$ denotes the elasticity of employment with respect to output, $y_{c j s}$ denotes output (in $\operatorname{logs}$ ) and $\Delta$ denotes the first difference operator. ${ }^{13}$ The exact structure of the industry and size class breakdowns are described in Section 3.1 and in Table 2. Time indices are dropped for expositional convenience. Note that the elasticities, obtained by estimating equation 2.1 for each firm group, are assumed to be time-invariant. The predicted aggregate employment growth rate at the country level, $\widehat{\Delta l}_{c}$ can then be written as the weighted average predicted employment

data. Therefore, estimating a linear model using annual firm-level data is not inconsistent with underlying models that specify non-linear adjustment costs (Hamermesh, 1993). Indeed, the simulation results by LaFontaine and Sivadasan (2009) confirm that the relationship between the underlying friction and the estimated $\beta$ and $\gamma$ coefficients in a reduced form regression such as equation 2.1 is preserved under various types of adjustment costs.

${ }^{10} \mathrm{We}$ use difference-GMM with the $3 \mathrm{rd}$ to the 5 th lags of the labour input and output as instruments. These lags were chosen for computational feasibility, such that the lagged instrument levels have sufficient explanatory power while maintaining orthogonality. As the estimates are carried out cell-by-cell and including year fixed effects, cell-level time-varying factors are controlled for.

${ }^{11}$ The literature does not provide tests or even a rule of thumb to see whether the number of instruments is 'too' large relative to sample size. Increasing $j / N$ filters less $\beta_{c j s}$-observations and therefore leads to a larger sample size in the second stage (the institutional analysis) However, it also increases the probability that observations are noisier.

${ }^{12}$ We do not consider earnings-per-worker dynamics during the crisis since in this case the decomposition would also have to account for the role of composition effects adding to the complexity of the exercise.

${ }^{13}$ Of course, elasticities are estimated, using equation 2.1 , and not directly observed, but for easier exposition, we write $\beta$ instead of $\widehat{\beta}$. 
growth rates over industry and firm size cells:

$$
\widehat{\Delta l}_{c}=\sum_{j=1}^{J} \sum_{s=1}^{S} w_{c j s} \underbrace{\left(\beta_{c j s} \Delta y_{c j s}\right)}_{\widehat{\Delta l} l_{c j s}}
$$

where $w_{c j s}$ denotes the employment share of size class $s$ and industry $j$ in country $c$ aggregate employment in the base period. Using this definition, $w_{c j s}$ captures heterogeneity in employment structures, $\beta_{c j s}$ captures heterogeneity in employment responses, and $\Delta y_{c j s}$ captures heterogeneity in output shocks.

To quantify the role of each source of heterogeneity, we decompose equation 2.3 into two components:

$$
\widehat{\Delta l}_{c}=\underbrace{\sum_{g=1}^{G} w_{c g}\left(\beta_{c g}-\bar{\beta}_{g}\right) \Delta y_{c g}}_{A_{c}}+\underbrace{\sum_{g=1}^{G} w_{c g} \bar{\beta}_{g} \Delta y_{c g}}_{B_{c}},
$$

where we introduce index $g$ for the group of firms defined by sizeclass and industry (thus $G$ denotes thus the total number of sizeclass and industry combinations) and cross-country average response heterogeneity in a firm group is given $\bar{\beta}_{g}=\frac{1}{C} \sum_{c=1}^{C} \beta_{c g}$. The first component $A_{c}$ captures the degree of heterogeneity in responses or elasticities $\beta_{c g} .{ }^{14}$ The second component $B_{c}$ of 2.4 shows the predicted aggregate employment change that would arise if there were no response heterogeneity, i.e. when output changes and employment shares evaluated at the average response $\bar{\beta}_{g}$.

Coming back to the first term, $A_{c}$ in equation 2.4, it is important to realize that it includes the combined effect of response heterogeneity measured by $\beta_{c g}-\bar{\beta}_{g}$ and the joint distributions of $w_{c g}$ and $\Delta y_{c g}$. As such, if $\beta-\bar{\beta}, w$ and $\Delta y$ are correlated, then the contribution of heterogeneity, term $A_{c}$, stems not only from heterogeneity in the $\beta$-s, but also from the combined variation in $\beta-\bar{\beta}, w$ and $\Delta y$. We will refer to this term in the results section (Section 4) as "the contribution of response heterogeneity with interaction effects". To fully isolate the role of response heterogeneity, we consider another measure as well, without interaction effects. We do so by decomposing $A_{c}$ into a term where employment shares and output shocks are set to their respective cross-country averages in each group, and into other terms that capture the

\footnotetext{
${ }^{14}$ More precisely, it gives the weighted average deviation of elasticities from their group-specific cross-country averages.
} 
covariance structure of the variables:

$$
\begin{aligned}
A_{c}=\sum_{g=1}^{G} w_{c g}\left(\beta_{c g}-\bar{\beta}_{g}\right) \Delta y_{c g} & =\underbrace{\sum_{g=1}^{G} \bar{w}_{g}\left(\beta_{c g}-\bar{\beta}_{g}\right) \overline{\Delta y}_{g}}_{A_{c}^{\prime}}+ \\
& +\sum_{g=1}^{G}\left(w_{c g}-\bar{w}_{g}\right)\left(\beta_{c g}-\bar{\beta}_{g}\right) \overline{\Delta y}_{g}+ \\
& +\sum_{g=1}^{G} \bar{w}_{g}\left(\beta_{c g}-\bar{\beta}_{g}\right)\left(\Delta y_{c g}-\overline{\Delta y}_{g}\right)+ \\
& +\sum_{g=1}^{G}\left(w_{c g}-\bar{w}_{g}\right)\left(\beta_{c g}-\bar{\beta}_{g}\right)\left(\Delta y_{c g}-\overline{\Delta y}_{g}\right),
\end{aligned}
$$

where $\overline{\Delta y}_{g}=\frac{1}{C} \sum_{c=1}^{C} \Delta y_{c g}$ and $\bar{w}_{g}=\frac{1}{C} \sum_{c=1}^{C} w_{c g}$ are the cross-country means of output growth and employment share in cell or firm group $g$. The first term on the right side of $2.5, A_{c}^{\prime}$, captures that part of employment growth which is associated with heterogeneity in responses alone. We refer to this part as the "contribution without interaction effects".

On the potential importance of the remaining terms $A_{c}-A_{c}^{\prime}$, i.e. the interaction effects, consider the following example. Suppose that countries with high (above-average) employment sensitivity $\beta_{c g}$ in a given group of firms, say small construction firms, also tend to have a larger employment share $w_{c g}$ and/or experience a larger output shock $\Delta y_{c g}$ in that group. For instance, the large fall in aggregate employment in Spain may be a combination of a large output shock hitting small construction firms, a large employment response to the shock and relatively high employment share of those firms. In this case, the contribution of response heterogeneity is likely to be relatively large, partly because of the role of interaction effects along these three dimensions. This is the motivation to consider to role of response heterogeneity without taking account of these interaction effects.

How to implement a variance decomposition in this setting? In order to calculate the contribution of each source of heterogeneity to the cross-country variation in employment growth, we make use of an implication of the definition of variance. Consider again equation 2.4. The cross-country variance of the left-hand-side of it can be written as: ${ }^{15}$

$$
\begin{aligned}
\operatorname{var}\left(\widehat{\Delta l}_{c}\right) & =\operatorname{var}\left(A_{c}+B_{c}\right)=\operatorname{var}\left(A_{c}\right)+\operatorname{var}\left(B_{c}\right)+2 \operatorname{cov}\left(A_{c}, B_{c}\right) \\
& =\operatorname{cov}\left(A_{c}, \widehat{\Delta l}_{c}\right)+\operatorname{cov}\left(B_{c}, \widehat{\Delta l}_{c}\right) .
\end{aligned}
$$

Equation 2.6 allows one to quantify how much of the cross-country variance of employment growth is explained by $A_{c}$ and $B_{c}$ separately. If $\operatorname{cov}\left(A_{c}, \widehat{\Delta l}_{c}\right)$ is large relative $\operatorname{var}\left(\widehat{\Delta l}_{c}\right)$, then most of the cross-country variation in employment growth is attributed to cross-country heterogeneity of responses and their interactions with structures and shocks. Thus we will focus on

\footnotetext{
${ }^{15}$ Using the definition of the covariance, and if $Z=X+Y$, we have that (i) $\sigma_{Z}^{2}=\sigma_{X}^{2}+\sigma_{Y}^{2}+2 \sigma_{X Y}$ and (ii) $\sigma_{Z X}=\sigma_{X}^{2}+\sigma_{X Y}$ and (iii) $\sigma_{Z Y}=\sigma_{Y}^{2}+\sigma_{X Y}$. Then (i)-(iii) imply $\sigma_{Z}^{2}=\sigma_{Z X}+\sigma_{Z Y}$.
} 
the ratios

$$
\begin{array}{r}
\text { Role of response heterogeneity with interactions: } \frac{\operatorname{cov}\left(A_{c}, \widehat{\Delta l}_{c}\right)}{\operatorname{var}\left(\widehat{\Delta l}_{c}\right)} \\
\text { Role of response heterogeneity without interactions: } \frac{\operatorname{cov}\left(A_{c}^{\prime}, \widehat{\Delta l}_{c}\right)}{\operatorname{var}\left(\widehat{\Delta l}_{c}\right)}
\end{array}
$$

which represent the share of cross-country variation in employment growth due to response heterogeneity with and without interaction effects.

Analogously to the steps we described above for response heterogeneity, which uses deviations from the cross-country means in elasticities $\beta_{c g}-\bar{\beta}_{g}$, we calculate the role of the two other sources of heterogeneity as well: output shocks and employment structure. They use deviations from cross-country means in output shocks and employment shares also with and without interaction effects.

\subsection{Analyzing the role of institutions}

One challenge when trying to identify the role of policies and institutions is that institutions are typically defined at the country-level and are correlated with each other across countries (Bassanini et al., 2010; Belot and van Ours, 2004) For instance, employment protection legislation tends be stronger in countries where other employees have other means of protection as well, in the form of trade unions, more generous unemployment benefits etc. This makes it difficult to isolate the role of a single institution using cross-country data unless all institutional effects are effectively accounted for in the regression analysis. One way to get around this problem is to focus on the available within-country variation of a given institution as this is less likely to be correlated across institutions. ${ }^{16}$ We consider two important labour market institutions that may have important implications for the adjustment behavior of firms, and which have data availabilities allowing us to utilize within-country as well as cross-country variation: employment protection provisions by exploiting firm-size exemptions and the role of temporary work by considering its incidence across firm types.

The institutional analysis uses the cell-by-cell estimates of the output elasticities $\hat{\beta}_{c g}$ of employment and earnings per workers based on equation 2.1 as the dependent, left-hand side variable. ${ }^{17}$ The impact of the institution of interest is identified by relating the within-country variation in output elasticities to the within-country variation, or more precisely, by comparing the variation in these two variables across firm types within countries and comparing them across

\footnotetext{
${ }^{16}$ In fact, if institution $X 1$ is correlated with institution $X 2$ in a country, and within-country variation is available, then the role of $X 2$ can be controlled for and therefore the least squares estimate of the effect of $X 1$ on the left-hand side variable can be identified. However, if $X 1$ is defined such that its variation is uncorrelated with $X 2$ by definition, there is no need to include $X 2$ in a regression measuring the effect of $X 1$. This is the case for the first institution: we make use of firm size exemptions in the case of EPL. The role of temporary work is gauged using incidence measures across firm groups within countries.

${ }^{17}$ Note that the cell structure is defined separately for each institutional variable in order to ensure that the within-country variation in the estimated output elasticities matches that of the institutional variable of interest. For instance, if an institution is available by a different size class or industry breakdown than our baseline classification, then we adjust the classification to match that of the institutions, and re-run the first stage regressions to obtain output elasticities $\beta_{c g}$-s.
} 
countries. In this sense, our estimation can be considered a generalized difference-in-difference approach that controls for both country and cell-specific fixed effects. ${ }^{18}$

Formally, the empirical model to identify the role of institutions can be represented in generic form as follows:

$$
\hat{\beta}_{c g}=\alpha I N S T_{c g}+\mu_{c}+\eta_{g}+\varepsilon_{c g}
$$

where $\hat{\beta}_{c g}$ denotes the first stage estimates of the employment and earnings-per-worker elasticities by firm group $g$ and country $c, I N S T_{c g}$ is the institutional variable of interest, and $\mu_{c}$ and $\eta_{g}$ are group- and country specific fixed effects, respectively. Country-specific fixed effects are important as they control for omitted labour market institutions, while group-specific fixed effects control for systematic differences in production technologies and their potential implications for labour adjustment. The coefficient $\alpha$ is our parameter of interest. It captures the effect of institutions on responsiveness under the identifying assumption that the variation in the elasticities after conditioning on cell and country fixed effects can be attributed to institutions. ${ }^{19}$

\subsubsection{Employment protection legislation (EPL)}

The effect of EPL is identified using variation generated by exemptions from national regulations (Venn, 2009). Exemptions usually apply to small firms but the exemption threshold may differ across countries. ${ }^{20}$ Exemptions may be full or partial and relate to individual or collective dismissals, denoted by $E P R_{c s}$ and $E P C_{c s}$, respectively. ${ }^{21}$ In general, the effect of more stringent regulations is expected to reduce employment responsiveness by increasing the costs of adjustment. Consequently, one would also expect firm size exemptions, i.e. looser employment protection for small firms, to reduce the fixed cost of adjusting the number of employees. This leads to stronger adjustment, i.e. larger $\beta$ elasticities, resulting in a negative coefficient $\alpha<0$ in equation. ${ }^{22}$ The identification assumption is that firms above and below the size-threshold differ only in terms of the applicable EPL-regime and are identical otherwise. If this assumption holds, any measured differences between the elasticities each side of the threshold can be attributed to EPL. To maintain the homogeneity of the sample along dimensions other than EPL, only those firms are taken into account whose employment level is either above or below the threshold throughout the entire sample period which is used for measuring output elasticities.

One potential concern with identifying the role of EPL from firm-size exemptions is that

\footnotetext{
${ }^{18}$ The "first" difference is defined by within-country deviations in elasticities and institutional variables. The "second" difference is given by the difference in these differences across countries. Comparing the differences gives a measure of the effect of institutions. Our approach may be considered a generalized DiD approach in the sense that we focus on continuous rather than binary variables (i.e. institutions like $E P L$ are measured on a continuous scale)

${ }^{19}$ To account for the fact that the dependent variable is generated by a "first stage" regression (equation 2.1 ) the second-stage regressions use robust standard errors. We also ran the second stage regressions with using the standard errors of the first stage as weights, which did not affect the results.

${ }^{20} \mathrm{~A}$ number of previous country studies have exploited the firm-size exemptions to study the economic implications of employment protection provisions (see Venn, 2010, and references therein). However, to the best of our knowledge, ours is the first study which does this on a cross-country basis.

${ }^{21}$ The stringency of EPL does not vary across industries, but only across countries and size classes. Therefore $E P R$ and $E P C$ are indexed only by country $c$ and sizeclass $s$.

${ }^{22}$ Theoretical models give some background to interpret results of the regressions below. For instance, Pissarides (2001) suggests that firing restrictions may be rationalized in the presence of market imperfections, which prevent workers from insuring against the risk of dismissal. On the other hand, EPL may hinder labour adjustment and therefore the efficient re-allocation of resources.
} 
its estimated impact may be biased because it captures the independent or autonomous effect of firm size. For example, employment in small firms has traditionally been considered more sensitive to output shocks than employment in large firms due to the role of credit constraint, leading to a biased estimate of the impact of EPL on the responsiveness of employment to output shocks away from zero. However, more recent evidence by Postel-Vinay and Moscarini (2011) as well as the results in Section 4.1 of this paper show that the employment elasticity, if anything, increases with firm size, suggesting that the bias may go in the other direction.

We control for the independent effect of firm size in two complementary ways. First, we include firm-size dummies which capture any common effects of firm size across countries. This is done either by assuming that the independent effect of firm size does not depend on the level of threshold or by allowing for heterogeneous firm-size effects for each threshold. In the first, more restrictive setting, it is sufficient to include a single dummy that equals one for observations above the threshold and is zero otherwise. This dummy is denoted by $v$ below. In the second setting, a separate firm-size dummy is included for each threshold. These are denoted by $v_{s}$.

The second way of controlling for independent firm size effects is by including "control" countries that do not provide firm size exemptions in their EPL. The inclusion of control countries is important as it may otherwise not be possible to disentangle independent firm-size effects that are common across countries from threshold effects (particularly when using the restricted model that assumes a common threshold effect across different thresholds)

Formally, the empirical model used to identify the impact of EPL on output elasticities is described as follows:

$$
\hat{\beta}_{c j s}=\alpha_{E P R} E P R_{c s}+\alpha_{E P C} E P C_{c s}+\eta_{j}+\mu_{c}+v_{s}+\varepsilon_{c j s}
$$

where $\mu_{c}$ denotes a set of country dummies, $\eta_{j}$ a set of industry dummies, and $v_{s}$ a set of size dummies, which allow for threshold-specific size effects. In the restricted version of the model where there is assumed to be a common threshold effect, the size dummy $v_{s}$ is replaced by $v$ and the interpretation is effectively a uniform above vs. below threshold difference, irrespective of the exact value of the threshold (e.g. 10 or 15 employees, etc.) The coefficients $\alpha_{E P R}$ and $\alpha_{E P C}$ measure the average effect of EPL, conditional on size and country-fixed effects. ${ }^{23}$

A second potential concern is that firms may systematically sort around the EPL threshold, depending on their adjustment technologies. In particular, firms that have higher output elasticities of employment are more affected by the presence of EPL. The reason is that it increases the fixed costs of adjusting the number of employees, thus hurts more those types of firms who would have more flexible adjustment in the absence of EPL. This provides incentives for firms to choose a small size which will make them exempt from EPL. This type of selection is likely to

\footnotetext{
${ }^{23}$ While equation 2.8 provides the intuition, in practice, we also include the interaction of the size-class dummy with an indicator for being above or below the threshold. The reason for this is that in order to have a sufficient number of observations in each cell for the estimation of the elasticities, we use "overlapping cells". This means that a firm can be in the "above" group for the sample around the threshold at 10 employees, but in the "below" group for the sample around the threshold at 20 employees. Then the size-class dummy selects which threshold we are focusing on, and the above dummy selects whether the firm is above or below the particular threshold. For the control countries, where no EPL exemptions exist, we define above and below samples for each possible threshold. For the treatment countries, where EPL exemptions exist, we only define above and below samples with respect to the actual threshold.
} 
raise the average output elasticity of employment below the threshold relative to those above the threshold, only by changing the pool of firms below the threshold. It may lead to a downward bias (away from zero) in the estimated impact of EPL on the employment elasticity.

In order to check whether the selection problem is serious in our case, we looked for signs of bumping or heaping in the firm size distribution. If this is important in practice, then observations should congregate below the thresholds, and/or we should observe spikes in the distribution of firm size. In contrast, the size distributions do not show unusual bunching at the thresholds (see Section B in the Appendix). ${ }^{24}$

\subsubsection{The incidence of temporary work}

The effect of temporary work on responsiveness can, in principle, be investigated by using another component of the EPL index which refers to provisions with respect to temporary contracts (Venn, 2009). However, because of particular concerns over the enforcement of these provisions, we prefer to focus on the incidence of temporary work instead (Bassanini et al., 2010). The main reason why enforcement issues are of particular concern in the context of temporary contracts is that incentives for enforcement are weak since workers and firms often share a mutual interest in non-enforcement. As a result, it has sometimes been difficult to establish a negative relationship between the incidence of temporary work and the stringency of employment protection provisions with respect to temporary contracts. Bassanini et al. (2010) provide empirical evidence that shows that this is indeed related to the problem of enforcement. Hence, instead of using information based on the legislation, we focus on the actual use of temporary work, by measuring its incidence across countries and firm groups. Of course, the exogeneity of such a measure is more questionable, but by including country fixed effects and relying on within-country variation at least eliminates the concern of other, omitted institutions driving the results.

The effect of temporary work on the responsiveness of employment and earnings per worker to output shocks is identified using the following model:

$$
\hat{\beta}_{c j s}=\alpha_{t e m p} T E M P_{c j s}+\mu_{c}+\eta_{j}+v_{s}+\varepsilon_{c j s}
$$

where $\hat{\beta}_{c j s}, \mu_{c}, \eta_{j}$ and $v_{s}$ are as before. TEMP denotes the incidence of temporary work within a cell, measured on a scale of $[0,1]$, by the ratio of temporary workers to total workers in a cell.

\section{Data and implementation}

This section describes the data sources used for the analysis. For the estimation of output elasticities, we make use of a comprehensive multi-country firm-level panel dataset, called ORBIS.

\footnotetext{
${ }^{24}$ Spain, Slovenia, Italy and Portugal, show no major discontinuities in their employment distribution around the thresholds. For a number of other countries, there are spikes in the distributions at every 5 or 10 employees, possibly linked to some rounding in reporting. We attempted to carry out formal tests for breaks in the distribution around the threshold (following McCrary, 2008), but the the discrete nature of the employment distribution makes it difficult to obtain reliable results. The recent results by Hijzen et al (2013) lend support to our case, however, as their tests fails to find a break at the threshold using a continuous (full time equivalent) measure of employment levels for Italy.
} 
For the purposes of the decomposition exercise discussed in Section 3.2, we make further use of a variety of data sources based on administrative information or labour force surveys. Third, for the institutional analysis we combine our cell-level output elasticities with semi-aggregated information of employment protection and the incidence of temporary work.

\subsection{Cross-country firm-level longitudinal database (ORBIS)}

We estimate output elasticities, as described in 2.1, using a cross-country, firm-level longitudinal database, called ORBIS. The dataset provides comparable information from balance sheets and income statements for firms across many OECD and non-OECD countries. It is collected by Bureau van Dijk via national sources. ${ }^{25}$ The Statistics Department (STD) of the OECD has carried out extensive consistency checks and cleaning of the data (see Ragoussis and Gonnard, 2012, for details) The cleaning procedure developed by the Statistics Department was applied and extended to take account of specific issues in relation to the present analysis. For the purposes of this project, the OECD/ORBIS dataset was complemented with previous vintages of ORBIS and Amadeus (the "European edition" of ORBIS) to increase the time-horizon of the data.

We make use of firms in the non-farm, non-financial business sector in 20 OECD countries for the period 1993 to 2009. Our "raw" sample for the analysis of employment adjustment was obtained after suppressing all observations with non-positive information on sales and employment. Similarly, our raw sample for the analysis of earnings per worker was obtained after suppressing all observations with non-positive information on sales, employment and earnings per workers. We further cleaned the two raw samples by applying a variety of cleaning rules (see Section A.1 in the Appendix) Table 1 provides information on the number of observations before and after applying these additional cleaning rules to the employment and earnings-per-worker samples. Of the 20 OECD countries, Austria and the United States had to be suppressed from the earnings-per-worker sample due the lack of comprehensive information on the wage bill. For more details, see Section A.1 in the Appendix.

For the purposes of the variance decomposition, described in Section 3.2, within-country heterogeneity is captured by stratifying the dataset along two dimensions: firm size and industry. Firm size is defined in terms of the average number of employees: less than 20 employees; between 20 and 250 employees; more than 250 employees. Industries are grouped into construction, manufacturing and business services. While the use of a limited number of groups may lead to ignore some differences in labour adjustment across firms, the use of a coarse cell structure makes it easier to highlight the main messages of the descriptive analysis and also allows enough observations within each cell to estimate output elasticities using equation 2.1.

\subsection{Administrative data sources}

In order to implement the decomposition of the cross-country variation in aggregate employment growth (see Section 2.2) the estimated output elasticities need to be complemented with celllevel information on output shocks (shock heterogeneity) and employment shares (structure

\footnotetext{
${ }^{25}$ Bureau van Dijk (BvD) is an electronic publishing firm collecting and providing company information and business intelligence.
} 
Table 1: The number of observations in the raw and estimation samples by country

\begin{tabular}{|c|c|c|c|c|}
\hline & $\begin{array}{c}\text { Raw data, } \\
\text { with nonmissing } \\
\text { employ ment and } \\
\text { sales }\end{array}$ & $\begin{array}{l}\text { Estimation } \\
\text { sample } \\
\text { (employment } \\
\text { equation) }\end{array}$ & $\begin{array}{c}\text { Raw data, } \\
\text { with nonmissing } \\
\text { earnings per } \\
\text { w orker and sales }\end{array}$ & $\begin{array}{l}\text { Estimation } \\
\text { sample } \\
\text { (earnings per } \\
\text { w orker eq.) }\end{array}$ \\
\hline Austria* & 95,766 & 15,821 & 8,643 & 0 \\
\hline Belgium & 334,093 & 199,297 & 333,696 & 186,808 \\
\hline Denmark & 47,267 & 27,770 & 45,204 & 24,034 \\
\hline Estonia & 193,835 & 76,488 & 156,854 & 53,740 \\
\hline Finland & 348,238 & 160,314 & 333,007 & 148,181 \\
\hline France & $3,731,112$ & $1,315,958$ & $2,875,705$ & $1,213,286$ \\
\hline Germany & 751,920 & 301,071 & 88,062 & 24,654 \\
\hline Hungary & 167,826 & 3,342 & 160,013 & 2,923 \\
\hline Italy & $1,799,317$ & 882,582 & $1,728,013$ & 821,097 \\
\hline Japan & $1,316,334$ & 793,330 & 680,111 & 282,031 \\
\hline Korea & 559,768 & 232,362 & 526,431 & 191,181 \\
\hline Netherlands & 43,989 & 16,253 & 29,257 & 7,759 \\
\hline Norway & 412,995 & 248,630 & 400,343 & 95,742 \\
\hline Poland & 203,788 & 113,938 & 148,205 & 71,593 \\
\hline Portugal & 781,587 & 11,452 & 761,775 & 10,433 \\
\hline Slovenia & 65,323 & 33,597 & 64,985 & 31,473 \\
\hline Spain & $3,826,199$ & $1,874,398$ & $3,804,147$ & $1,690,616$ \\
\hline Sw eden & $1,077,407$ & 455,476 & 927,112 & 360,381 \\
\hline United Kingdom & 415,647 & 342,794 & 387,501 & 288,927 \\
\hline United States* & $10,975,640$ & 58,516 & 10 & 0 \\
\hline Overall sum & $27,148,051$ & $7,163,389$ & $13,459,064$ & $5,504,859$ \\
\hline Overall mean & $1,357,403$ & 358,169 & 708,372 & 289,729 \\
\hline
\end{tabular}

Note: non-farm, non-financial business sector, 1993-2009. The raw sample for the employment (earnings per worker) analysis corresponds to observations with strictly positive values for sales, employment (and earnings per worker) The raw data is different from the estimation sample due to restrictions on minimum firm size (at least 3 employees) basic cleaning and outlier-filtering, and most importantly, concentrating on firms with at least five valid observations. Smallest and largest cells refer to the cells with the least and largest number of observations, considering nine cells based on three broad sectors (manufacturing, construction and business services) and three firm size classes (less than 20 employees, between 20 and 250 employees, more than 250 employees) Countries marked with * are excluded from the earnings per worker sample because of the low number of observations. For more details, see Section A.1 in the Appendix and Section 3.1.

Source: Authors' calculations based on ORBIS 
heterogeneity) To ensure that our decomposition is consistent with official aggregate information, we rely as much as possible on external data which are consistent with published national accounts and nationally representative labour force surveys.

The measures of structure heterogeneity are constructed by combining two data sources. First, information on the employment shares of manufacturing, construction and services by country and year are obtained from OECD STAN. Second, since OECD STAN does not provide any information by firm size, we multiply the employment shares by industry by time-invariant employment shares of firm-size groups within industries obtained from the Structural and Demographic Business Statistics (SDBS) ${ }^{26}$

Cell-level output changes by industry and firm size are measured as follows. First, changes in real output by industry, country and year are obtained from OECD STAN. Second, cell-level output changes are calculated using the year-on-year evolution of real sales in ORBIS. Third, the growth rates of size classes within an industry, calculated from ORBIS, are rescaled such that the weighted-average growth rate of these size classes equals the industry-level growth rate observed in STAN. ${ }^{27}$

The data on employment shares (structure heterogeneity) and output changes (shock heterogeneity) are summarised in Table 2. It is worth pointing out some interesting findings from there. First, Spain and Portugal had above average construction sectors, while, together with Italy, had also a lot of employment concentrated in small firms. Second, output declines tended to be largest in the manufacturing sector, except Spain, Portugal, the UK and the US where it was concentrated in construction. Third, Estonia was especially hard hit in each of the sectors.

\subsection{Data on labour market institutions}

The institutional analysis considers employment protection and the incidence of temporary work. Information on the stringency of employment-protection rules with respect to collective and individual dismissals are obtained from the OECD database on EPL described in Venn (2009) Table A.2 of the Appendix provides details on the stringency of employment protection provisions for countries that practice firm-size exemptions or are included in our estimation sample as control countries. Exemptions in relation to individual dismissals (EPR) are partial in all countries in the sample, indicating that workers of small firms are subject to more flexible rules than larger firms. This generally reflects shorter or no notice periods, different procedural requirements or lower levels of severance pay. The other sub-component of EPL which we include in the analysis refers to collective dismissals rules (EPC). In countries where small firms are exempt from

\footnotetext{
${ }^{26}$ While the SDBS, in principle, provides information on employment and the number of firms by country, year, industry and firm-size class, this information is typically missing from 2008 onward. We, therefore, use the average values of the employment shares in 2006-2007 and assume these are constant over time. Any missing information in STAN on cell-level employment was imputed using chained labour force surveys.

${ }^{27}$ Cell-level output growth rates are rescaled as follows:
}

$$
\Delta y_{c j s t} \doteq \Delta y_{c j s t}^{O R B I S} \frac{\Delta y_{c j t}^{S T A N}}{\Delta y_{c j t}^{O R B I S}}
$$

where $\Delta y_{c j t}^{S T A N}$ and $\Delta y_{c j t}^{O R B I S}$ denote output growth rates in country $c$, industry $j$ and year $t$ from STAN and ORBIS, respectively. Cell-level output growth rates $\Delta y_{c j s t}^{O R B I S}$ are calculated as sales weighted average output growth rates across firms within a cell. 
Table 2: Cross-country differences in economic structure and the distribution of output shocks Panel A: Cross-country differences in economic structure ("structure heterogeneity") Share of firm groups, in \%, out of total employees (2008)

\begin{tabular}{l|ccc|ccc}
\hline & \multicolumn{3}{|c|}{ Firm size group } & \multicolumn{2}{c}{ Industry } \\
\cline { 2 - 7 } & $\begin{array}{c}\text { Less than } 20 \\
\text { employees }\end{array}$ & $\begin{array}{c}21-250 \\
\text { employees }\end{array}$ & $\begin{array}{c}251 \text { employees } \\
\text { and more }\end{array}$ & Construction & Manufacturing & Services \\
\hline Belgium & 39.7 & 27.5 & 32.8 & 9.7 & 22.1 & 68.2 \\
Denmark & 30.1 & 35.8 & 34.1 & 11.3 & 23.0 & 65.7 \\
Estonia & 37.2 & 42.7 & 20.1 & 18.3 & 31.1 & 50.6 \\
Finland & 32.0 & 28.3 & 39.7 & 12.5 & 29.1 & 58.4 \\
France & 34.2 & 27.9 & 37.8 & 11.9 & 21.3 & 66.8 \\
Germany & 31.4 & 30.7 & 38.0 & 8.6 & 29.8 & 61.6 \\
Hungary & 43.7 & 27.9 & 28.5 & 12.1 & 35.6 & 52.3 \\
Italy & 58.7 & 22.7 & 18.6 & 12.0 & 31.0 & 57.0 \\
Japan & 39.4 & 29.9 & 30.7 & 12.2 & 25.3 & 62.5 \\
Korea & 41.1 & 28.8 & 30.1 & 11.8 & 26.4 & 61.7 \\
Netherlands & 38.2 & 29.8 & 32.0 & 9.3 & 17.7 & 73.0 \\
Norway & 44.7 & 27.9 & 27.4 & 13.0 & 20.0 & 67.1 \\
Poland & 43.6 & 27.4 & 29.0 & 12.5 & 36.1 & 51.4 \\
Portugal & 51.9 & 29.8 & 18.3 & 16.7 & 28.0 & 55.3 \\
Slovenia & 38.0 & 30.5 & 31.6 & 13.1 & 36.6 & 50.3 \\
Spain & 48.3 & 29.4 & 22.2 & 18.9 & 22.6 & 58.5 \\
Sweden & 34.3 & 30.0 & 35.7 & 11.0 & 27.9 & 61.1 \\
United Kingdom & 31.4 & 24.4 & 44.2 & 11.4 & 15.9 & 72.7 \\
United States & 42.4 & 25.8 & 31.8 & 10.7 & 16.8 & 72.5 \\
\hline
\end{tabular}

Panel B: Cross-country differences in output shocks ("shock heterogeneity") Percentage change in real output by firm groups (2008-09)

\begin{tabular}{|c|c|c|c|c|c|c|}
\hline & \multicolumn{3}{|c|}{ Firm size group } & \multicolumn{3}{|c|}{ Industry } \\
\hline & $\begin{array}{c}\text { Less than } 20 \\
\text { employees }\end{array}$ & $\begin{array}{c}21-250 \\
\text { employees }\end{array}$ & $\begin{array}{c}251 \text { employees } \\
\text { and more }\end{array}$ & Construction & Manufacturing & Services \\
\hline Belgium & -3.6 & -4.4 & -4.4 & -3.6 & -7.5 & -3.1 \\
\hline Denmark & -10.2 & -11.0 & -11.0 & -13.7 & -15.9 & -8.6 \\
\hline Estonia & -21.2 & -23.6 & -21.8 & -35.4 & -27.7 & -15.1 \\
\hline Finland & -9.6 & -11.6 & -11.5 & -13.6 & -18.8 & -6.6 \\
\hline France & -4.1 & -5.4 & -5.1 & -5.9 & -14.1 & -1.7 \\
\hline Germany & -5.6 & -8.3 & -10.1 & -0.9 & -18.9 & -3.9 \\
\hline Hungary & -7.9 & -10.5 & -11.3 & -6.5 & -15.4 & -6.4 \\
\hline Italy & -7.4 & -11.0 & -8.9 & -7.0 & -17.2 & -4.2 \\
\hline Japan & -10.9 & -12.7 & -8.4 & -6.9 & -16.9 & -8.9 \\
\hline Korea & -0.9 & -1.3 & -1.4 & 2.5 & -2.2 & -1.4 \\
\hline Netherlands & -5.6 & -6.1 & -5.9 & -4.3 & -9.2 & -5.3 \\
\hline Norway & -2.6 & -3.1 & -3.3 & -0.5 & -5.2 & -2.7 \\
\hline Poland & 1.4 & 0.5 & 0.7 & -0.5 & -0.7 & 2.4 \\
\hline Portugal & -4.4 & -6.3 & -4.2 & -10.6 & -9.1 & -1.4 \\
\hline Slovenia & -12.7 & -15.2 & -15.4 & -18.8 & -20.6 & -8.8 \\
\hline Spain & -4.8 & -7.2 & -5.8 & -6.4 & -14.4 & -2.3 \\
\hline Sweden & -7.7 & -9.9 & -11.1 & -5.6 & -19.8 & -5.9 \\
\hline United Kingdom & -6.5 & -7.2 & -6.1 & -11.3 & -11.3 & -4.8 \\
\hline United States & -6.8 & -7.1 & -6.3 & -13.4 & -9.1 & -5.3 \\
\hline
\end{tabular}

Note: In the non-farm, non-financial business sector.

Source: Authors' calculations based on ORBIS, SDBS and labour force surveys. For more details, see the text in Section 3 . 
collective dismissal rules, the value of EPC is $0 .^{28}$

Data on the incidence of temporary work by industry and firm-size cell are obtained from the European Labour Force Survey.

\section{Results}

First, we present and comment on the estimated labour adjustment parameters across countries and firm groups using the methodology described in Section 2.1. Then, by using the output elasticities, we conduct the variance decomposition, described in Section 2.2, to assess the role of response, shock and structure heterogeneity and their interactions in shaping cross-country patterns of employment adjustment. The role assigned to response heterogeneity is interpreted as an upper bound for the role of labour market institutions, at least for short-run adjustment. In doing so, we rely on the assumption made in Section 2, that labour market institutions affect elasticities but not employment shares or the size of the shocks in the short run. Finally, we identify the role of EPL and temporary work for shaping the adjustment behaviour of firms, following the methodology in Section 2.3.

\subsection{Elasticities of labour market outcomes}

Figure 2 describes the estimated responsiveness of labour input to output shocks. ${ }^{29}$ On average, across countries, the short-term elasticities of employment and earnings-per-worker are both between 0.1 and 0.15 , with the sensitivity of employment to output shocks being slightly larger than that of earnings-per-worker. This suggests that, at least in terms of the cross-country averages, contemporaneous adjustments on the extensive (employment) and intensive margins (average hours worked and wages) to output shocks account both for a substantial part of total labour-cost adjustment. However, there appears to be considerable heterogeneity in the cross-country distribution of elasticities, with a strong negative correlation between the output elasticities of employment and earnings per worker (the pairwise correlation is - 0.5 and statistically significant) This implies that firms that adjust more on the employment margin tend to adjust less on the earnings-per-worker margin. The elasticity of employment with respect to output is highest in countries such as Denmark and the United States, while it is lowest in Central and Eastern European Countries (CEECs) and Japan. The earnings-per-worker elasticity is highest in Hungary, Japan and Poland and lowest in Italy, Portugal and Spain. The former results echo earlier findings on the flexible US and Danish labour markets, while the latter findings are broadly in line with those of the Wage Dynamics Network of the European Central Bank, showing that real wages in the CEECs are generally more flexible than in more developed EU countries (Babecky et al 2009; Heinz and Rusinova, 2011).

The cross-country averages of elasticities for each industry show that the responsiveness of employment to output is highest in construction and lowest in manufacturing, while the respon-

\footnotetext{
${ }^{28}$ This reflects the fact that a firm needs to have a certain critical mass to engage in collective dismissals.

${ }^{29}$ These elasticities are estimated separately for each firm size, industry and country. In Figure 2, unweighted averages are shown as we do not want the relative size of cells to affect the picture. Coefficients on the lagged dependent variable are also of interest but not discussed here as the main purpose is to explain the short-term impact of the crisis on labour markets.
} 
siveness of earnings-per-worker is highest in manufacturing and lowest in construction. The differences in elasticities are quantitatively large, with the employment (earnings-per-worker) elasticity in construction being about twice as large (small) as that in manufacturing. These may reflect differences in production technologies, the skill composition of the workforce or the importance of non-standard contracts. The large differences across sectors in the responsiveness of labour inputs to output shocks imply that cross-country differences in industrial structure and the sectoral concentration of shocks can have important implications for the impact of the crisis on labour markets.

Differences in the responsiveness of labour inputs to output shocks across size groups are less pronounced than those across industries, but are of particular interest as they do not appear to conform well to the perceived wisdom at first sight. According to the figure, the responsiveness of both employment and earnings-per-worker to output shocks increases with firm size. This suggests that the sensitivity of the wage bill also increases with firm size. Traditionally, however, employment in small firms has been considered to be more sensitive to output shocks than employment in large firms, because the former were thought to find it more difficult to hoard labour during periods of weak product demand due to financial constraints (Sharpe, 1994) ${ }^{30}$ This argument implies that the sensitivity of both employment and earnings-per worker to output should decline with firm size. However, the traditional view that small firms hoard less during a downturn has recently been challenged by Postel-Vinay and Moscarini (2011) who suggest that large firms may have weaker incentives to retain workers during a downturn since they tend to be more productive and offer higher wages and, as a result, find it easier to recruit new workers during a recovery. ${ }^{31}$ This argument is, in principle, consistent with the positive relationship between the sensitivity of employment and firm size, but does not explain the positive relationship between earnings-per-worker and firm size.

\subsection{Variance decomposition of aggregate employment growth during the global financial crisis}

In order to examine the role of structure, shock and response heterogeneity for aggregate employment growth during the global financial crisis, the cross-country variation in aggregate employment growth between 2008 and 2009 is decomposed into components that are assumed to capture different sources of heterogeneity (see Section 2.2 for details) The contribution of each source of heterogeneity to the cross-country variance is calculated in two ways. First, for each source of heterogeneity, we switch off the two other sources of heterogeneity by setting their values to the cross-country average (equation 2.5) This is labelled "contribution without interaction effects" in Figure 3. Computing the explained variance in this manner gives a measure of the explanatory power of a single source. Second, for each source of heterogeneity, we leave the other two at the actual values (equation 2.4) Computing the explained variance in this manner gives a measure of explanatory power when each source of heterogeneity is evaluated at the actual distribution. If heterogeneity is correlated along these dimensions, computing con-

\footnotetext{
${ }^{30}$ Small firms tend to have shorter credit histories, to be subject to higher levels of idiosyncratic risk and are less likely to have adequate collateral (Gertler and Gilchrist, 1994)

${ }^{31}$ Descriptive statistics based on firm-level data for a large number of European countries in OECD (2010) are also at odds with the traditional view and consistent with the evidence in Postel-Vinay and Moscarini (2011)
} 
Figure 2: Differences in the sensitivity of labour inputs to output shocks ("response heterogeneity")

Estimated output elasticities across countries, industries and firm size groups

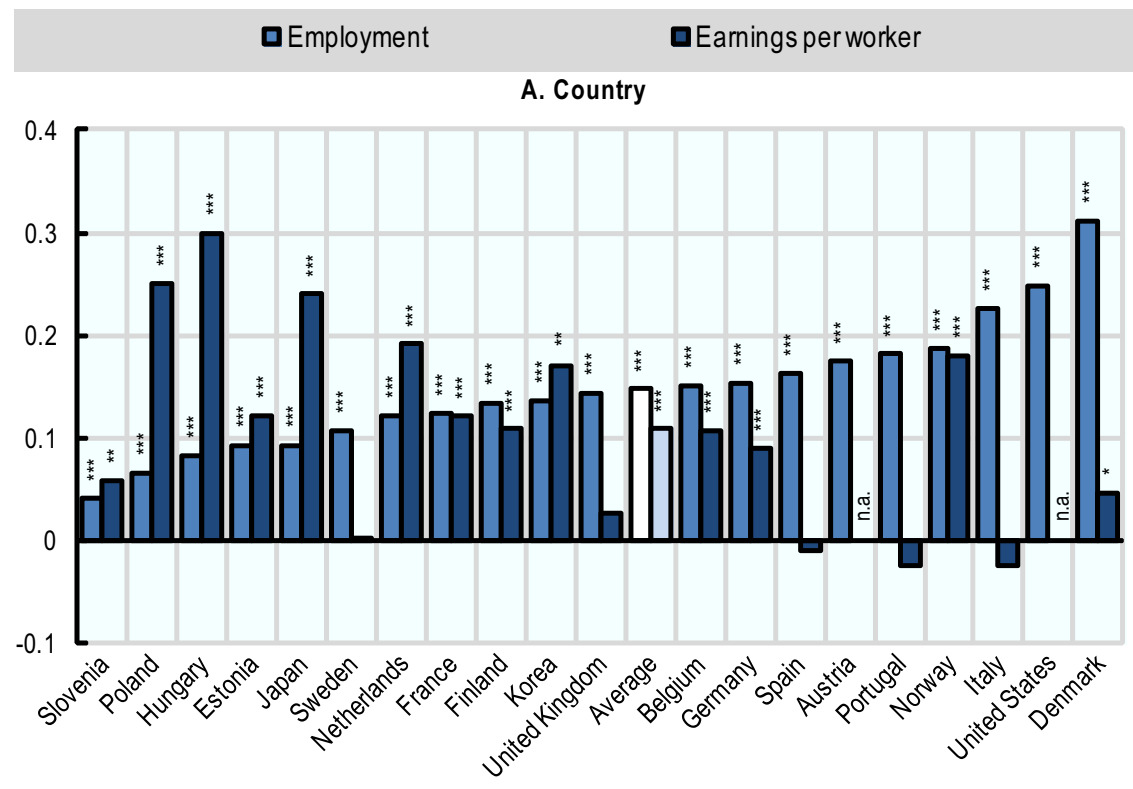

B. Industry and firm size group

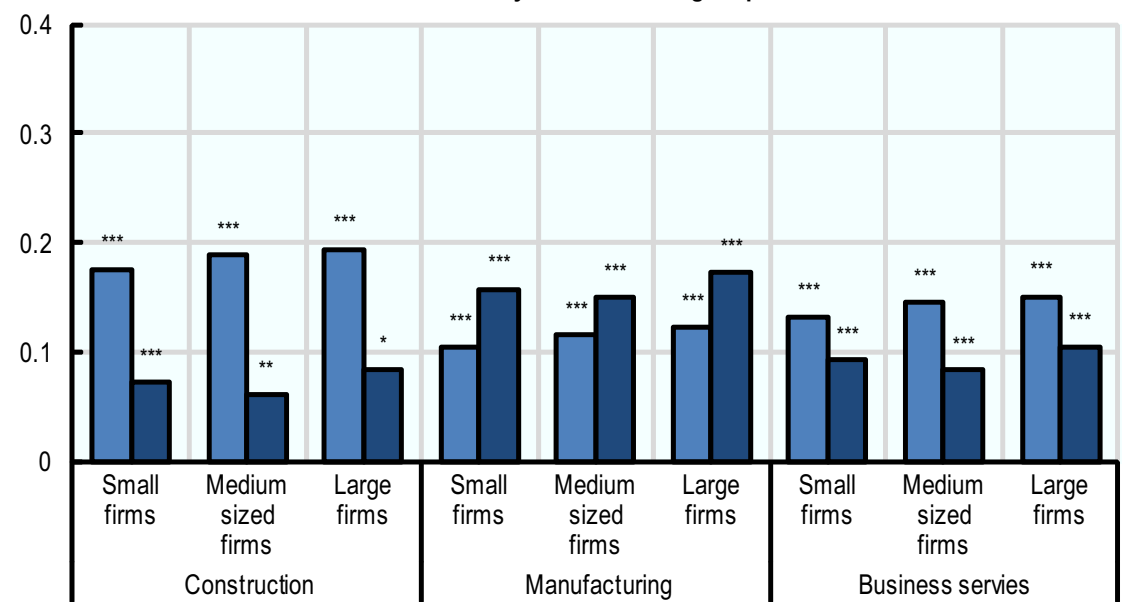

$*, * *, * * *$ statistically significant at the $10 \%, 5 \%$ and $1 \%$ level, respectively.

n.a.: Not available.

Note: unweighted averages over cells by country (panel A) and over countries by cells (panel B)

Source: Authors' calculations based on ORBIS. 
Figure 3: Decomposition of cross-country variation in labour market adjustment during the crisis

Contributions to cross-country variance in employment growth rates, from 2008 to 2009

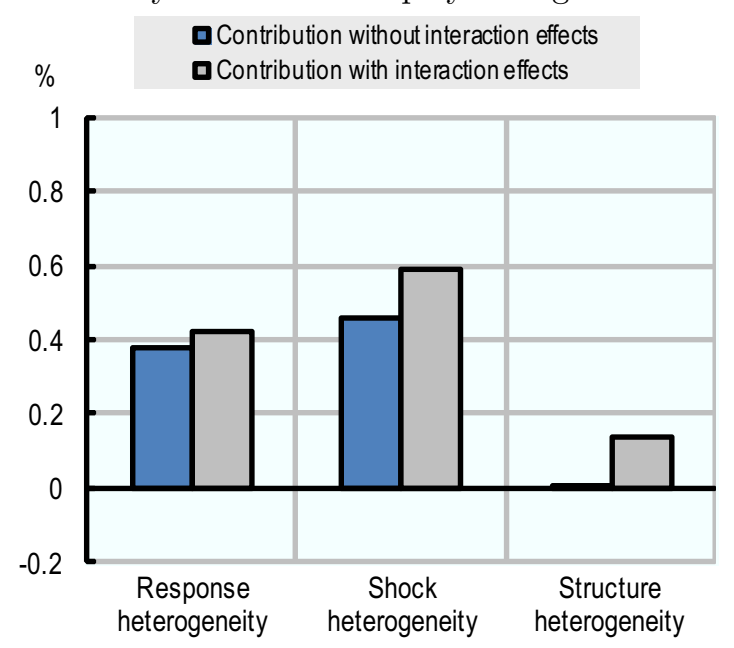

Source: Authors' calculations based on ORBIS, STAN, LFS and SDBS. For details, see Section 2.2.

tributions in this manner should increase the explained variance. This is labelled "contribution with interaction effects".

The results from the decompositions are presented in Figure 3. Response heterogeneity explains $38 \%$ of the cross-country variation in employment growth when the other variables are kept at their cross-country mean. Considering the sample distributions of employment shares and output shocks, the contribution of response heterogeneity goes up slightly to $42 \%$ of the cross-country variation. Repeating the decomposition for shock heterogeneity suggests that this source explains $46 \%$ of the cross-country variation in employment growth. After accounting for the covariances between output shocks, on the one hand, and employment shares and output responses, on the other, shock heterogeneity explains about $59 \%$ of the cross-country variation in employment growth. The role of structure heterogeneity is negligible without accounting for interaction effects but increases to $14 \%$ after accounting for such effects.

The results provide two key insights. First, the relative importance of response heterogeneity suggests that differences in policies and institutions across countries account for a potentially large part of the cross-country variation in aggregate employment growth during the crisis. Second, using disaggregate information can indeed explain part of differences in aggregate labour market dynamics, as illustrated by the share of the cross-country variance that can be attributed to the role of interactions.

\subsection{Results of the institutional analysis}

This section presents evidence on the effect of labour market regulations on the responsiveness to shocks. As a first plausibility check on our estimated elasticities and their relationship with labour market institutions, we present the relationship between employment protection and labour market flexibility using only cross-country variation. Then we move on to present our main results which use micro-level elasticities and within-country variation in employment protection, followed by suggestive evidence on the role of temporary work. 
Figure 4: Cross-country relationship between employment protection and employment adjustment

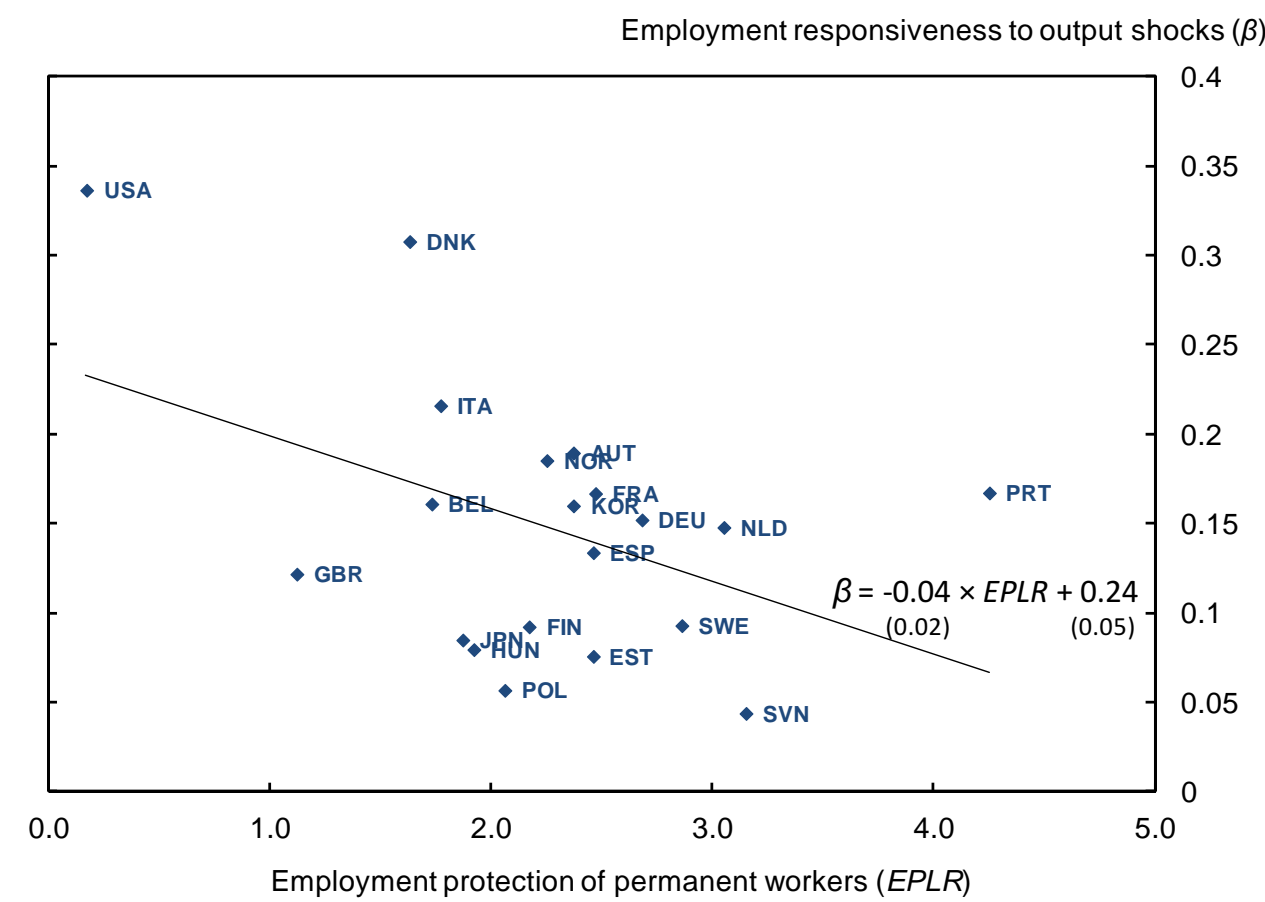

Note: Employment responsiveness to shocks are measured as the median values of the firm-level GMM estimates of elasticities $\beta$ across firm groups (cells) based on equation 2.1. See more on firm-level estimation in Section 2.1. Employment protection of permanent workers is the median value of the first subindex of the EPL measure (Venn, 2009) over the years 1998-2009.

Source: Venn, 2009 and authors' calculations based on ORBIS.

\subsubsection{The role of employment protection using cross-country variation}

Figure 4 shows a scatter plot of the regular component of the EPL index $(E P L R)$ and the estimated employment elasticities of output shocks (the median $\beta$-s across firm groups, for each country) The relationship is negative (and significant at 5\%) as expected: more stringent employment protection, by increasing the costs of adjustment, generally leads to smaller adjustment to output shocks. Although this finding is in line with economic intuition and earlier evidence (Bassanini and Duval, 2009; OECD, 2012) it meant to be only an illustrative exercise, since no additional controls are included. As we argued in the introduction, the most important controls would be further institutional and policy variables, which can affect both labour market flexibility and usually tend to be related to the stringency of employment protection. To focus only on employment protection and filter out the impact of other policies and institutions, the next subsection exploits within-country variation of the EPL index.

\subsubsection{The role of employment protection using within-country variation}

This part of the analysis of employment protection exploits the within-country variation that results from firm-size exemptions. In order to ensure that the results only relate to exemptions with respect to employment-protection provisions and not the independent effect of firm size the analysis control for common firm-size effects across countries and, in addition, includes countries without firm-size exemptions as controls (see Section 2.3 for details) The results for employment 
Table 3: The effect of EPL of responsiveness on the responsiveness of employment and earnings per worker

\begin{tabular}{l|cccc}
\hline \multirow{2}{*}{ Dismissal for regular w orkers } & \multicolumn{3}{|c}{ A. Employment } & \multicolumn{3}{c}{ B. Earnings per worker } \\
\cline { 2 - 5 } & -0.031 & $-0.045^{* *}$ & $0.184^{*}$ & $0.164^{*}$ \\
Collective dismissals & $(-1.55)$ & $(-2.47)$ & $(2.12)$ & $(2.13)$ \\
& -0.010 & 0.003 & 0.001 & 0.003 \\
Size effect & $(-1.26)$ & $(0.74)$ & $(0.16)$ & $(0.32)$ \\
& $-0.030^{* * *}$ & n.a. $^{+}$ & $0.045^{* * *}$ & n.a. $^{+}$ \\
Flexible size effect & $(-3.71)$ & & $(4.99)$ & \\
Number of observations & No & Yes & No & Yes \\
\hline
\end{tabular}

$*, * *, * * *$ : statistically significant at the $10 \%, 5 \%$ and $1 \%$ level, respectively. $t$ statistics in parentheses

+ There is no uniform size effect to reported in columns A (2) and B (2) as the impact is allowed to flexibly vary with the thresholds.

Note: Column 1 shows results with constant size effects (equation 2.8 with a uniform $v$ for above-below effects, in Section 2.3) Column 2 shows results for flexible size effects (equation 2.8 with a firm-size dependent $v_{s}$ ) All specifications include a full set of country and industry fixed effects. For details, see Section 2.3.

are reported in Table 3 .

The results suggest a negative relationship between the stringency of individual dismissal regulations for regular workers and the responsiveness of employment to output shocks. As shown by the first row of Panel A, a unit-increase in the index of EPL is associated with 3-5 percentage point decrease in the employment elasticity, similar to the magnitude obtained using cross-country variation (Figure 4) On the other hand, the stringency of collective dismissals does not seem to be significantly related to employment elasticities in our sample. There is evidence of independent size effects around the threshold: the coefficient of $v$ is statistically significant at $5 \%$ when we assume a uniform above-below effect (columns 1 and 3 ) as well as when we allow it to vary with the thresholds (not shown in table).

The responsiveness of earnings per worker to output shocks appears to be positively associated with the stringency of individual-dismissal provisions (3, Panel B) The relationship seems to be robust across specifications and even stronger than for employment adjustment. Again, there is evidence of positive size effects around the threshold: the coefficient of $v$ is positive and statistically significant.

The results of specification (2.8) are visualized in Figure 5. They indicate that provisions with respect to both individual and collective dismissals have a tendency to reduce the output elasticity of employment, while provisions with respect to individual dismissals appear to increase the sensitivity of earnings per worker to output shocks. Moreover, the effects of individual dismissal provisions appear to be large. A one standard-deviation increase in the stringency of individual dismissal provisions, which corresponds to an increase in the level from Denmark to Belgium, would result in a 4 percentage-point reduction in the responsiveness of employment to output shocks and a 10 percentage-point increase in the responsiveness of earnings-per-worker to output shocks. These results suggest that more stringent employment-protection provisions 
Figure 5: The effect of employment protection on labour input responsiveness

Output elasticities of employment and earnings per worker,

with EPR and EPC at average values and with high values

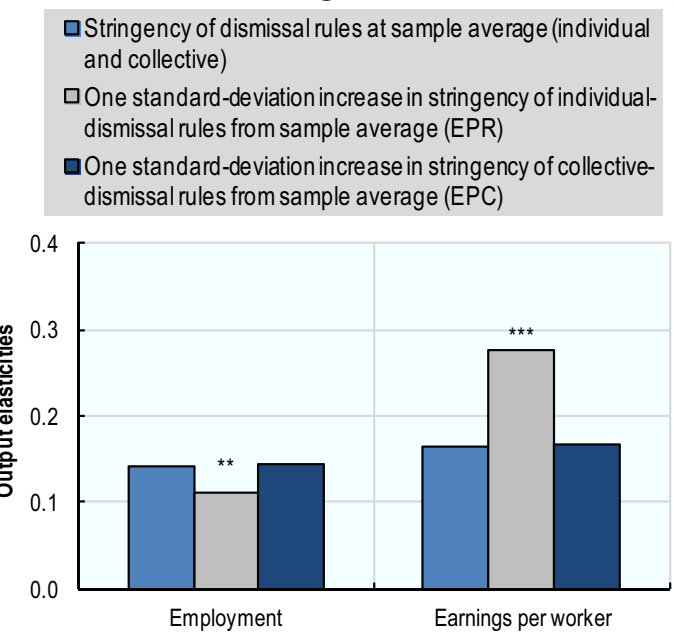

$* *, * * *$ : statistically significant at the $5 \%$ and $1 \%$ level, respectively.

For details, see Section 2.3.

for regular employees induce firms to adjust less on the extensive and more on the intensive margin.

\subsubsection{The role of the incidence of temporary work}

Employment protection rules are also likely to have an important impact on the use of temporary contracts (Blanchard and Landier, 2002; Boeri, 2011) Employment protection provisions with respect to regular contracts increase incentives to make use of temporary contracts, while employment protection provisions with respect to temporary contracts regulate their use. In order to capture the impact of employment protection on the adjustment behaviour of firms that comes about through its impact on the incidence of temporary work, Figure 6 analyses the role of the incidence of temporary work for the adjustment behaviour of firms. It confirms expectations that the employment sensitivity of temporary workers with respect to output shocks is substantially higher than that of regular workers. There is some indication that the increased sensitivity of employment reduces the sensitivity of earnings per worker in response to shocks. However, the difference in the sensitivity of earnings per worker to shocks between permanent and temporary workers is not statistically significant.

\section{$5 \quad$ Aggregate implications}

What does the evidence above suggest about the importance of a specific policy or institution in explaining the cross-country variation of employment growth during the crisis? In order to answer this question, we check how much the dispersion of cross-country employment growth is affected by setting the employment protection index referring to individual dismissals of regular workers (EPR) to the cross-country average. More specifically, we calculate the dispersion of 
Figure 6: The effect of the incidence of temporary work on labour input responsiveness

Output elasticities of employment and earnings per worker, with temporary work incidence at average values and with high values

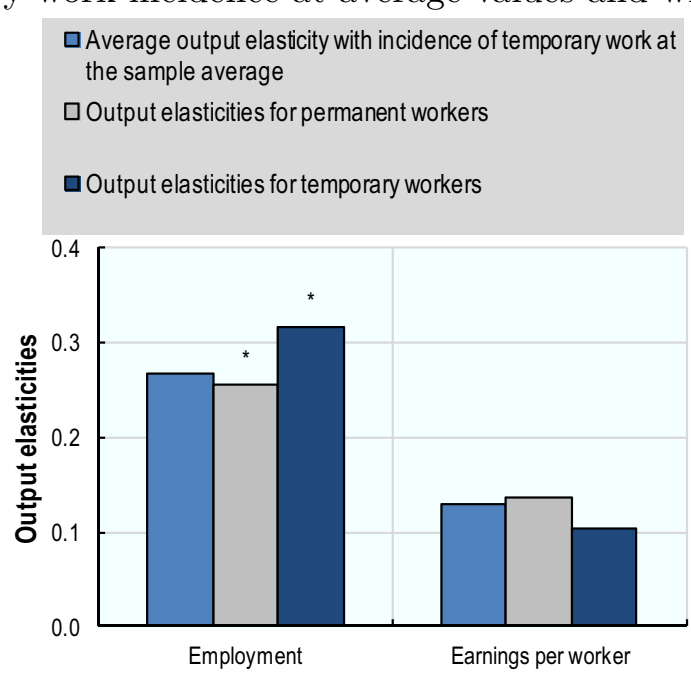

**, ***: statistically significant at the $5 \%$ and $1 \%$ level, respectively. Output elasticities for permanent and temporary workers denote the average of predicted values of regression 2.9 when setting the incidence of temporary work to one and to zero

Source: Authors' calculations based on ORBIS. For details, see Section 2.3.

the implied country-level employment growth rates between 2008 and 2009 across countries

$$
\sigma\left(\widehat{\Delta l}_{t}\right) \doteq \sqrt{\frac{1}{N_{c}-1} \sum_{c=1}^{C}\left(\widehat{\Delta l}_{c t}-\widehat{\widehat{\Delta l}}_{t}\right)^{2}}
$$

where $N_{c}$ is the number of countries and $\widehat{\widehat{\Delta l}}_{t}$ is the average of the predicted aggregate employment change across countries. The implied country-level employment changes are calculated according to the formula in equation 2.3 in the Section 2.2, which uses estimated cell-level employment elasticities $\widehat{\beta}_{c g}$, actual output changes $\Delta y_{c g}$ and actual employment shares $w_{c g}$ in country $c$ and firm group $g$. We repeat that formula here, with time subscripts omitted, and emphasize that estimated $\beta$-s are now treated as a function of the components of EPL, as obtained in the 2nd stage regressions (equation 2.8):

$$
\widehat{\Delta l}_{c}=\sum_{g=1}^{G} w_{c g}\left(\widehat{\beta}_{c g} \Delta y_{c g}\right)
$$

The standard deviation of the predicted employment changes across countries $\sigma(\widehat{\Delta l})$ is $0.9 \%$ in 2009. Using the estimated coefficient of $E P R$ on the output elasticity of employment from Panel B of Table $3(-0.47)$ we calculate the predicted elasticities after setting EPR to its crosscountry mean:

$$
\widetilde{\beta}_{c g} \doteq \widehat{\beta}-0.47 \times\left(\overline{E P R}_{c g}-E P R_{c g}\right)
$$


and use these elasticities in equation 5.1:

$$
\widetilde{\Delta l} c=\sum_{g=1}^{G} w_{c g}\left(\widetilde{\beta}_{c g} \Delta y_{c g}\right)
$$

The resulting cross-country standard deviation is $0.8 \%$, only slightly smaller than the standard deviation based on actual levels in EPR.

Thus, this simple back-of-the-envelope calculation indicates that differences in the regular worker component of EPL alone are unlikely to be a major cause for the dispersion in aggregate employment dynamics during the initial phase of the global financial crisis. In future work, further institutions like tax systems the nature of collective bargaining, could be looked at in order to explain a larger part in the variation of labour adjustment across countries. ${ }^{32}$

\section{Concluding remarks}

This paper investigates the role of policies and institutions for aggregate labour market dynamics during the global financial crisis using firm-level data. It makes the case that using micro-level information can be important for understanding macro-economic outcomes in the context of firm heterogeneity and provides new evidence on the role of labour market institutions for the adjustment behaviour of firms.

The use of firm-level data is important if firms are heterogeneous in their labour input adjustment technologies. In this case, cross-country differences in aggregate labour market dynamics may not just stem from cross-country differences in average labour input technologies - here assumed to be largely due to differences in institutional settings -, but also from differences in the distribution of shocks across firms within countries and the composition of firms across countries. Descriptive evidence based on a variance decomposition suggests that this may indeed be important in practice. Thus, using disaggregate information not only enhances one's ability when adjustment technologies are non-linear as emphasized in previous related work, but also when firms are heterogeneous in terms of their adjustment technologies.

Firm-level data may also help to shed more light on the role of labour market institutions for the way firms adjust in response to shocks. In contrast to much of the previous literature on the role of labour market institutions the present paper does this by exploiting the withincountry variation in institutions rather than the cross-country variation. The main advantage of doing so is that the within-country variation allows us to better estimate the effect of a single institutional variable. Moreover, using disaggregate data also allows controlling for different sources of heterogeneity. Estimates from aggregate studies may be misleading to the extent that cross-country differences in labour market adjustment results, in part, from differences in composition of firms or the distribution of business conditions across firms.

This paper shows that labour market institutions account employment protection provisions for regular workers have a tendency to shift the burden of adjustment from the extensive margin (employment) to the intensive margin (working time and wages) while the incidence of temporary

\footnotetext{
${ }^{32}$ Alternatively, our assumption that output elasticities are constant over time may not be valid during the crises. Perhaps the perceived persistence of the shocks, or other types of shocks (e.g. financial) and changing labour market policies (regulation of short-term work) can also play a role.
} 
tends to have the opposite effects. However, back-of-the-envelope calculations on the effects of EPL for regular workers suggest that they are unlikely to account for a substantial part of the cross-country variation in aggregate employment dynamics during the initial phase of the global financial crisis. Hence, exploring the role of other labour market institutions as well is an important area of future research. 


\section{Appendix}

\section{A Data description}

\section{A.1 Sources and construction of international firm-level data}

The source of the company-level dataset used in the analysis is the ORBIS dataset, collected by the Bureau van Dijk $(\mathrm{BvD})^{33}$ The database is a collection of accounts, mostly at annual frequency, derived from companies' balance sheets and income statements. As such, it is a longitudinal database providing rich variation across countries, industries and firm size, and with a time span of seventeen years (1993-2009) $)^{34}$ The version we can access contains data from 43 countries (primarily OECD member countries and those who participate in the Enhanced Engagement of the OECD) though not all of them can be used in the analysis. Eventually 21 countries were included in the sample, for which there is a large enough number of firms and the appropriate set of variables for our purposes. See Table 1 in the Section 3 of the main text for the set of countries we use and the number of observations and firms for each.

Our main variable of interest is employment (EMPLOYEES in ORBIS) sales or turnover (OPERATING_REV_TURNOVER) as a proxy for output and labour costs (COSTS_EMPLOYEES) Earnings per worker is defined as labour costs divided by employment.

All firms in our analysis have at least three consecutive years of non-missing and positive data without implausibly large longitudinal changes. Specifically, as they are likely to be data errors, we filter out observations in any of the conditions are met in Table A.1. The main filtering rules were: i) to exclude observations with less than three employees; ii) to exclude firms with less than three consecutive observations and less than five observations in total (not necessarily consecutive); iii) to exclude observations with implausibly large changes in employment, sales or earnings per worker and iv) to exclude outliers based on sales per worker (i.e. labour productivity)

We also apply outlier filtering based on the distribution of sales over employment and earnings per worker: we apply the Chebyshev method and filter out observations in each country, industry and sizeclass cell which our outside the interval defined as $[p 25-1.5 * i q r, p 75+1.5 * i q r]$, where $p 25$ and $p 75$ denotes the 25 th and 75 th percentiles, and $i q r$ is the interquartile range: $i q r=p 75-p 25$.

After dropping observations which do not pass these filters, we require that each firm has at least five observations in order to ensure that the GMM type estimation can utilize enough number of lagged values. The affected number of observation per each country for each of these criteria is available on request.

\footnotetext{
${ }^{33}$ The ORBIS dataset, which contains countries outside as well as within Europe, is augmented with the Amadeus dataset (also collected by the BvD) This was needed primarily to include more firm-year observations in the 1990's, as the vintage of the ORBIS dataset available at the OECD starts reporting firms mostly only around 1999.

${ }^{34}$ The Statistics Department (STD) and at the Directorate of Employment, Labour and Social Affairs (ELS) of the OECD have carried out extensive consistency checks and cleaning of the data. Among others, the role of consolidated accounts, differing accounting years have been addressed. See more details on this by the OECD STD (Ragoussis and Gonnard, 2011)
} 
Table A.1: Criteria for filtering observations

\begin{tabular}{|c|c|c|c|c|c|c|}
\hline & \multirow[b]{2}{*}{ Definition } & \multirow{2}{*}{$\begin{array}{l}\text { Log changes, } \\
\text { controlling for } \\
\text { absolute changes as } \\
\text { well (in absolute } \\
\text { value) }^{a}\end{array}$} & \multirow{2}{*}{$\begin{array}{l}\text { Gross growth } \\
\text { rates }^{b}\end{array}$} & \multirow{2}{*}{$\begin{array}{c}\text { Reversals } \\
\text { (in gross growth } \\
\text { rates) }\end{array}$} & \multicolumn{2}{|c|}{$\begin{array}{c}\text { Log changes at the edges of a } \\
\text { firm-spell }^{d}\end{array}$} \\
\hline & & & & & Log changes & $\begin{array}{l}\text { Difference from } \\
\text { lagged log } \\
\text { changes }\end{array}$ \\
\hline \multicolumn{7}{|c|}{ A. Readily available variables } \\
\hline Employment & - & $\begin{array}{l}0.5 \text { log-points, more } \\
\text { than } 1000 \text { employees }\end{array}$ & 5 & 1.5 & 0.5 & 0.8 \\
\hline Sales & - & - & 6 & 6 & 0.7 & 0.9 \\
\hline Value added & - & - & 7 & 4 & 0.7 & 0.9 \\
\hline Labor costs & - & - & 6 & 2 & 0.6 & 0.6 \\
\hline Fixed tangible capital & - & - & 8 & 2 & - & - \\
\hline \multicolumn{7}{|c|}{ B Constructed variables } \\
\hline Earnings per worker & $\begin{array}{l}\text { Labour costs / } \\
\text { Employment }\end{array}$ & - & 0.8 & 0.5 & - & - \\
\hline $\begin{array}{l}\text { Labour productivity } \\
\text { (using sales) }\end{array}$ & $\begin{array}{l}\text { Sales / } \\
\text { Employment }\end{array}$ & - & 2 & 0.7 & - & - \\
\hline $\begin{array}{l}\text { Labour productivity } \\
\text { (using value added) }\end{array}$ & $\begin{array}{l}\text { Value added / } \\
\text { Employment }\end{array}$ & - & 3 & 1.5 & - & - \\
\hline Capital-labour ratio & $\begin{array}{l}\text { Fixed tangible capital / } \\
\text { Employment }\end{array}$ & - & 2.5 & 0.5 & - & - \\
\hline
\end{tabular}

Note: observations are dropped from the database if any of the criteria (columns) for any variable (rows) is not fulfilled. For example, the first entry in column four corresponds to the following rule: an observation is dropped if the yearly growth rate in employment grows by a factor of 5 or drops by $80 \%$. This rule is equivalent to keeping all observations which satisfy the following rule $1.2<E_{t} / E_{t-1}<5$. The relative magnitude of the intervals across variables are based on an assessment of the relative standard deviation of the variables.

a) Dropping observations with large absolute changes. An observation is dropped if the absolute value of log changes $\left|\log \left(X_{t} / X_{t-1}\right)\right|$ is larger than values in the respective cells of the table, and also the absolute value of changes in levels are larger than the value in the cell.

b) Dropping observations with large growth rates. An observation is dropped if $X_{t} / X_{t-1}$ is larger than the cell value or smaller than the inverse of the cell value.

c) Dropping observations with volatile growth rates (reversals) An observation is dropped if $X_{t} / X_{t-1}$ is above the cell value in time $\mathrm{t}$ and is below the inverse of the cell value in time $t+1$.

d) Dropping observations with volatile growth rates (lagged growth) An observation is dropped if the absolute value of log changes is larger than the elements in the first sub-column and the difference with the lagged change is larger than the elements in the second sub-column. 
Table A.2: Employment protection and firm-size exemptions

Stringency of employment-protection provisions for regular workers and collective dismissals

\begin{tabular}{|c|c|c|c|}
\hline & Firm size groups & EPLR & EPLC \\
\hline \multirow[t]{3}{*}{ Austria } & Less than 5 employees & 1.35 & 0.00 \\
\hline & 5-19 employees & 2.19 & 0.00 \\
\hline & 20 employees and more & 2.19 & 3.25 \\
\hline \multirow[t]{2}{*}{ Belgium } & Less than 20 employees & 3.10 & 0.00 \\
\hline & 20 employees and more & 4.14 & 4.13 \\
\hline \multirow[t]{2}{*}{ Denmark } & Less than 20 employees & 2.80 & 0.00 \\
\hline & 20 employees and more & 3.85 & 3.13 \\
\hline \multirow[t]{2}{*}{ Finland } & Less than 20 employees & 3.02 & 0.00 \\
\hline & 20 employees and more & 4.49 & 2.38 \\
\hline France & - & 2.60 & 2.13 \\
\hline \multirow[t]{3}{*}{ Germany } & Less than 10 employees & 0.43 & 0.00 \\
\hline & 10-19 employees & 2.85 & 0.00 \\
\hline & 20 employees and more & 2.85 & 3.75 \\
\hline \multirow[t]{2}{*}{ Hungary } & Less than 20 employees & 2.94 & 0.00 \\
\hline & 20 employees and more & 4.09 & 2.88 \\
\hline \multirow[t]{2}{*}{ Italy } & Less than 15 employees & 1.36 & 4.88 \\
\hline & 15 employees and more & 1.76 & 4.88 \\
\hline Japan & - & 2.05 & 1.50 \\
\hline Korea & - & 2.29 & 1.88 \\
\hline Norway & - & 2.20 & 2.88 \\
\hline Poland & - & 2.01 & 3.63 \\
\hline \multirow[t]{2}{*}{ Portugal } & Less than 10 employees & 3.18 & 1.88 \\
\hline & 10 employees and more & 3.51 & 1.88 \\
\hline \multirow[t]{2}{*}{ Slovenia } & Less than 10 employees & 2.72 & 2.88 \\
\hline & 10 employees and more & 2.98 & 2.88 \\
\hline \multirow[t]{3}{*}{ Spain } & Less than 25 employees & 2.26 & 2.13 \\
\hline & 25-49 employees & 2.46 & 2.13 \\
\hline & 50 employees and more & 2.38 & 3.38 \\
\hline United Kingdom & - & 1.17 & 2.88 \\
\hline \multirow[t]{2}{*}{ United States } & Less than 100 employees & 0.56 & 0.00 \\
\hline & 100 employees and more & 0.56 & 2.88 \\
\hline
\end{tabular}

- : Not applicable.

Note: EPL R denotes the stringency of firing regular workers, and EPL C measures the stringency of collective dismissals regulations in 2008. Source: Venn (2009)

\section{A.2 Employment protection index with firm size exemptions}

Table A.2 presents the degree of employment protection, pertaining to regular, permanent workers (EPL R) and collective dismissals (EPL C) for firms below and above the size thresholds, for countries where such size exemptions of applying employment protection are present. The data is taken from Venn (2009)

\section{B Firm size distributions by employment thresholds for firm- size exemptions}

Below we show the employment distribution of firms for those countries where employment protection legislation exempts small firms from the most stringent regulations. The threshold below firms are considered exempt vary by country, but 4 groups can be identified, with thresholds at employment levels of 10, 15, 20 and 25. The US, with the threshold at 100 employees, is omitted because the stringency of the more important, regular worker component (EPR) of the 
Figure B.1: Firm size distributions by employment thresholds for firm-size exemptions

(a) Slovenia (employment threshold: 10)

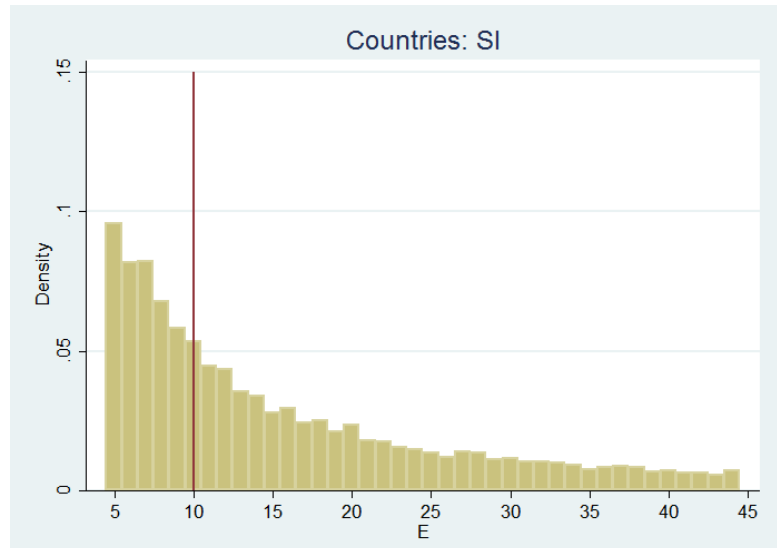

(c) Austria, Belgium, Denmark, Finland, Germany, Hungary (employment threshold: 20)

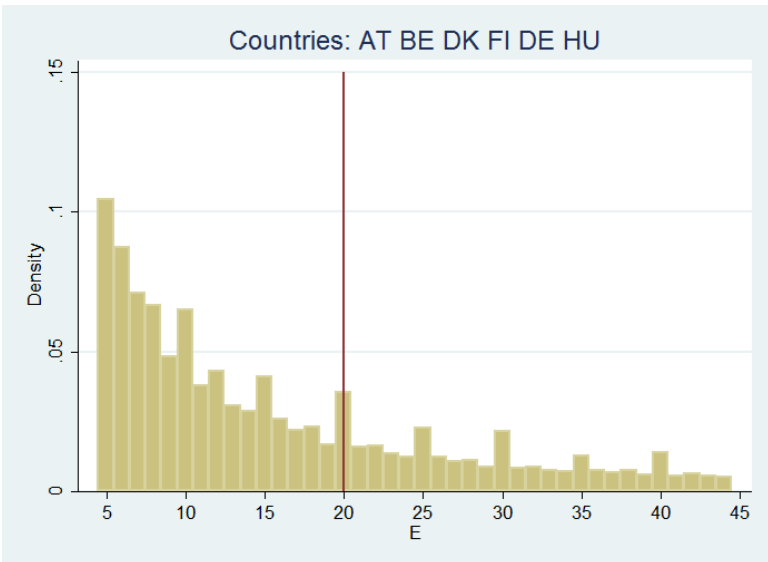

(b) Italy, Portugal (employment threshold: 15)

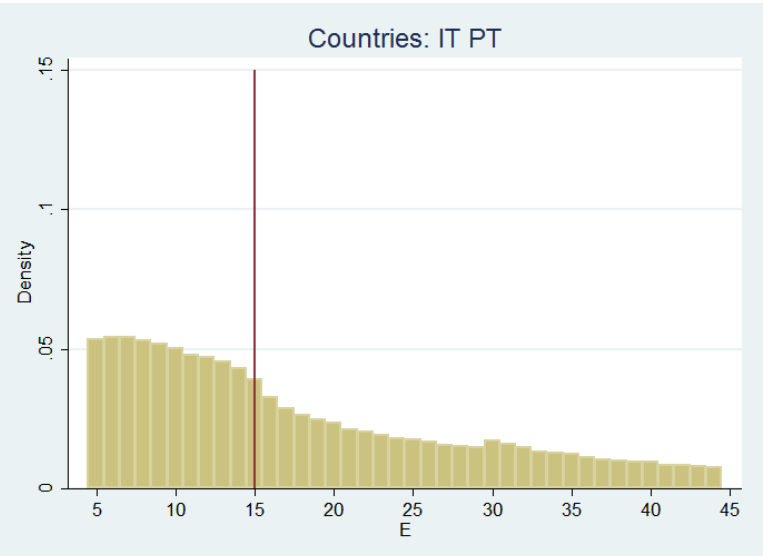

(d) Spain (employment threshold: 25)

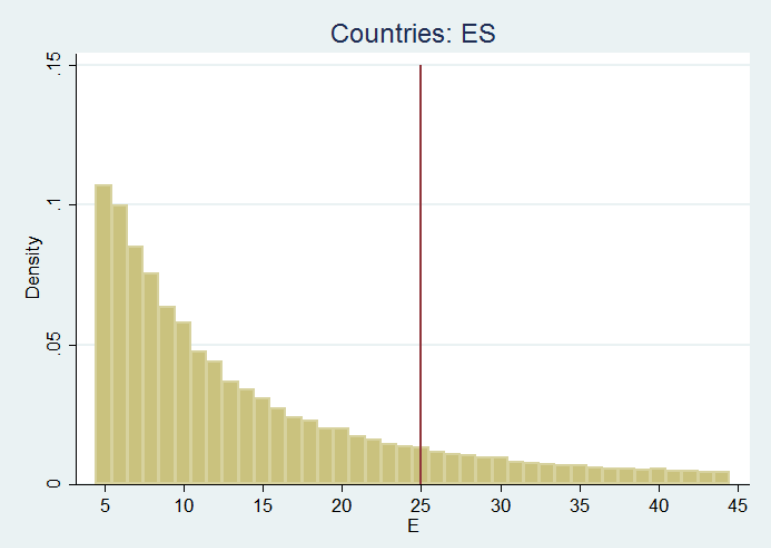

Note: horizontal axis denotes employment (E) the columns indicate the densities of the firms size (measured by employment) distribution by country-groups, grouped by the employment protection thresholds below which exemptions apply. Vertical lines indicate the country-group specific threshold levels (10, 15, 20 and 25)

EPL index is the same below and above the threshold, and the employment histogram is very irregular around such high employment levels due to low density of firms at such, relatively high employment level.

\section{References}

- Aidt, T.S. and Z. Tzannatos (2008) "Trade unions, collective bargaining and macroeconomic performance: a review", Industrial Relations Journal, Vol. 39, Iss. 4, pp. 258-295.

- Arellano, M. and S. Bond (1991) "Some Tests of Specification for Panel Data: Monte Carlo Evidence and an Application to Employment Equations", Review of Economic Studies, Vol. 58, No. 2, pp. 277-297.

- Autor, D. (2003) "Outsourcing at Will: Unjust Dismissal Doctrine and the Growth of Temporary Help Employment", Journal of Labor Economics, Vol. 21, No. 1, pp. 1-42. 
- Babecký, J., P. D. Caju, T. Kosma, M. Lawless, J. Messina and T. Rõõm (2009) "Downward Nominal and Real Wage Rigidity. Survey Evidence from European Firms", European Central Bank, Working Paper Series No. 1105.

- Ball, L. M., D. Leigh and P. Loungani (2013) "Okun's Law: Fit at 50?", IMF Working Papers 13/10, International Monetary Fund.

- Bassanini, A. and R. Duval (2009) "Unemployment, Institutions, and Reform Complementarities: Re assessing the Aggregate Evidence for OECD Countries", Oxford Review of Economic Policy, Vol. 25, pp. 40-59.

- Bassanini, A., A. Garnero, P. Marianna and S. Martin (2010) "Institutional Determinants of Worker Flows: A Cross-country/Cross-industry Approach", OECD Social, Employment and Migration Working Papers, No. 107, OECD Publishing, Paris.

- Bassanini, A., L. Nunziata and D. Venn (2009) "Job Protection Legislation and Productivity Growth in OECD Countries”, Economic Policy, Vol. 58, pp. 349-402.

- Belot, M., and Van Ours, J. (2004) 'Does the Recent Success of Some OECD Countries in Lowering their Unemployment Rates Lie in the Clever Design of their Labour Market Reform?', Oxford Economic Papers, 56(4) pp 621-42.

- Blanchard, O.J. and A. Landier (2002) "The Perverse Effects of Partial Labor Market Reform: Fixed Duration Contracts in France", Economic Journal, Vol. 112, pp. 214-244.

- Blanchard, O. and J. Wolfers (2000) "The Role of Shocks and Institutions in the Rise of European Unemployment: The Aggregate Evidence", Economic Journal, Vol. 110, pp. C1-C33.

- Bloom, N. (2009) "The Impact of Uncertainty Shocks", Econometrica, Vol. 77, Iss. 3, pp. 623-685.

- Boeri, T. (2011) "Institutional Reforms and Dualism in European Labor Markets", in O. Ashenfelter and D. Card (eds.) Handbook of Labor Economics, pp.1173-1236.

- Caballero, R., E. Engel, and J. Haltiwanger, (1997) "Aggregate Employment Dynamics: Building From Microeconomic Evidence”, American Economic Review, Vol.87, pp.115-137.

- Cingano, F., M. Leonardi, J. Messina and G. Pica (2010) "The effects of employment protection legislation and financial market imperfections on investment: evidence from a firm-level panel of EU countries", Economic Policy, Vol. 25, pp. 117-163.

- Davis, S.J., R.J. Faberman and J.C. Haltiwanger (2006)"The Flow Approach to Labour Markets: New Evidence and Micro-Macro Links", Journal of Economic Perspectives, 20, 3-24.

- Davis, S.J., R.J. Faberman and J.C. Haltiwanger (2011)"Labour Market Flows in the Cross Section and over Time", NBER WP 17294, Journal of Monetary Economics, forthcoming. 
- Calmfors, L. (1993) "Centralization of Wage Bargaining and Macroeconomic Performance - A Survey", OECD Economic Studies No. 21.

- Dougherty, S., V. C. F. Robles, K Krishna (2012) "Employment Protection Legislation and Plant-Level Productivity in India”, NBER Working Paper No. 17693 Du Caju, P., E.

- European Central Bank (2012) "Euro Area Labour Markets and the Crisis", Occasional Paper Series No 138.

- Gautier, D. M. and M. Ward-Warmedinger (2008) "Institutional Features of Wage Bargaining in 23 European Countries, the US and Japan", National Bank of Belgium Working Paper Research No. 154, December.

- Gertler, M. and S. Gilchrist (1994) "Monetary Policy, Business Cycles, and the Behavior of Small Manufacturing Firms," Quarterly Journal of Economics, Vol. 109(2) pp. 309-340.

- Gertler, M. and A. Trigari (2006) "Unemployment fluctuations with Staggered Nash Bargaining," NBER WP 12498.

- Gould, J. P. (1968) "Adjustment Costs in the Theory of Investment of the Firm", The Review of Economic Studies, Vol. 35(1) pp. 47-55

- Hamermesh, D. S. (1993) "Labor Demand", Princeton University Press, Princeton, New Jersey.

- Heinz, F. F. and D. Rusinova (2011) "How Flexible Are Real Wages in EU Countries? A Panel Investigation", European Central Bank, Working Paper Series No. 1360.

- Hijzen, A., L. Mondauto and S. Scarpetta (2013) "The Perverse Effects of Job-Security Provisions on Job Security in Italy: Results from a Regression Discontinuity Design", mimeo.

- Hobijn, B. and A Sahin (2012) "Beveridge Curve Shifts across Countries since the Great Recession," Federal Reserve Bank of San Francisco Working Paper Series No 2012-24.

- Kahn, L.M. (2007) "The Impact of Employment Protection Mandates on Demographic Temporary Employment Patterns: International Microeconomic Evidence", Economic Journal, Vol. 117, No. 521, pp. 333-356.

- Kennan, J. (2006) "Private Information, Wage Bargaining and Employment Fluctuations," NBER Woorking Paper No. 11967.

- LaFontaine, F., and J. Sivadasan (2009) "Do Labour Market Rigidities Have Microeconomic Effects? Evidence from within the Firm.", American Economic Journal: Applied Economics, Vol. 1(2) pp. 88-127.

- McDonald, M. and R.M. Solow (1981) "Wage Bargaining and Employment", American Economic Review, Vol. 71, No. 5, pp. 896-908.

- Menzio, G. (2005) "High Frequency Wage Rigidity," mimeo, University of Pennsylvania 
- McCrary, J. (2008) "Manipulation of the running variable in the regression discontinuity design: A density test," Journal of Econometrics, Vol. 142(2), pp 698-714.

- Moscarini, G. and F. Postel-Vinay (2011) "The Contribution of Large and Small Employers to Job Creation in Times of High and Low Unemployment", American Economic Review, forthcoming.

- Nickell, S J \& M. Andrews (1983) "Unions, Real Wages and Employment in Britain 195179," Oxford Economic Papers, Vol. 35, pp. 183-206.

- Nickell, S. and Layard, R. (1999) "Labor market institutions and economic performance", in: O. Ashenfelter \& D. Card (eds.) Handbook of Labor Economics, Vol. 3, Ch. 46, pp. 3029-3084.

- OECD (2006) Employment Outlook, OECD Publishing, Paris.

- OECD (2010) Employment Outlook, OECD Publishing, Paris.

- OECD (2012) Employment Outlook, OECD Publishing, Paris.

- Ragoussis, A. and E. Gonnard (2012) "The OECD-ORBIS database treatment and benchmarking procedures", mimeo OECD.

- Sharpe, S. A. (1994) "Financial Market Imperfections, Firm Leverage, and the Cyclicality of Employment", American Economic Review, Vol. 84, No. 4, pp. 1060-1074.

- Shimer, R. and R. Wright. (2004) "Competitive Search Equilibrium with Asymmetric Information," mimeo.

- Venn, D. (2009) "Legislation, Collective Bargaining and Enforcement: Updating the OECD Employment Protection Indicators", OECD Social, Employment and Migration Working Papers, No. 89.

- Venn, D. (2010) "The impact of small-firm exemptions from employment protection", mimeo OECD. 